\title{
Volatility spillovers across European stock markets under the uncertainty of Brexit
}

\begin{abstract}
This paper examines the behaviour of some inter-related European stock markets under the uncertainty of Brexit in a multivariate time-varying setting. Our results point to considerable interactions between these markets. As evident by the smaller and less frequent positive net total volatility spillovers, the UK's influence on the other markets has been decreasing since the campaign for the EU referendum started in January 2016. Although the shock of the Brexit decision on $23^{\text {rd }}$ June 2016 increases market volatility as expected, it exerts diverse impacts instantaneously on market co-movements. Although the ambivalent markets adjust rather quickly, synchronizing their movements within days, the impact of the Brexit decision on market co-volatility continues to be substantial and persists. Impact of the yet-progressmade trade agreement now under negotiation for resolution may as well be long lasting on the dynamics between markets.
\end{abstract}

JEL Classification: C31, C53, D53, and G15.

Keywords: Brexit, Volatility Spillover, Multivariate GARCH, Variance decomposition and Volatility impulse response. 


\section{INTRODUCTION}

The United Kingdom has chosen to leave the European Union (EU) through a historic referendum on $23^{\text {rd }}$ June 2016. The decision to withdraw from this longstanding EU membership has increased uncertainty for businesses and households across Europe to an elevated level, as evident by the increases of $68 \%$ and $118 \%$ in the European economic policy uncertainty index ${ }^{1}$ from 2015 to 2016 and from May to June 2016 respectively. As this withdrawal will not take place until the end of March 2019, businesses, especially financial services, which are intertwined across Europe are still facing uncertainty about what trade agreements will be like between the UK and EU in the coming years. Many studies, such as Hosoe (2018), Samitas et al. (2018) and Jackson and Shepotylo (2018), have attempted to examine the potential impact of the Brexit decision on the real economy by simulation. Similarly, Belke et al. (2018) assess the impact of the Brexit probability on the UK and international financial markets. A few other studies have rightfully attempted to observe how the stock markets reacted to the Brexit decision in order to gauge the expectations of the investors and businesses. For instance, While Ramiah et al. (2017) and Burdekin et al. (2018) examine the impact of the Brexit decision on stock returns of the British sectors or the global equity markets, Aristeidis and Elias (2018) and Nishimura and Sun (2018) investigate how stock markets around the world have interacted around the time of the EU referendum. To the best of our knowledge, however, the existing studies have not isolated or estimated specifically the impacts of Brexit-related events on stock market volatilities or co-volatilities.

How the stock markets interact under uncertainty is crucial for investment decision-making. A significant strand of literature has shown that in times of major economic and/or political events, stock market volatility increases dramatically and spills over across markets, causing

\footnotetext{
${ }^{1} \mathrm{http} / / / \mathrm{www}$. policyuncertainty.com/europe_monthly.html 2
} 
financial instabilities (see, among others, Forbes and Rigobon, 2002; Bloom, 2009; Diebold and Yilmaz, 2009 and 2012; and references therein). Measuring and monitoring the stock market interactions under uncertainty allows investors to develop effective hedging against shocks that are propagated across markets. Furthermore, gauging the depth and duration of volatility spillovers enables policy makers to identify a shock originated from one market that could destabilize another market. Hence, an examination of the impacts of Brexit-related events on volatility spillovers across the European stock markets and a contrast of these impacts with other shocks in 2016 could assist policy makers in identifying events that might threaten the institutional stability and in overcoming potential adverse effects across markets.

Motivated by such considerations, we will systematically examine the nature and intensity of the volatility spillover dynamics between the UK and five stock markets in Europe, comprising Germany, France, Ireland, Italy and Poland, between $2^{\text {nd }}$ January 2015 and $21^{\text {st }}$ October 2017. These stock markets are selected to contrast how members of the EU at different economic and financial developments or with ties to the UK to various extents would respond to shocks originated from the UK. As expected, Germany and France are included for their importance in the EU and for being competing financial centres to the UK. Ireland has developed a close relationship with the UK over many centuries, while Italy and Poland are relatively distant in terms of economic as well as geographic proximity with the UK. Moreover, Ireland is particularly relevant in any study on Brexit as its border with Northern Ireland of the UK has become a factor that determines whether the UK can smoothly exit the European Union. Italy is interesting additionally for being a focal point due to its disagreement with the EU on how to deal with its high level of bad bank loans and its vote on the constitutional reform in December 2016. Wallace and Chan (2016) warn that the financial problems arising from the Italian bad debt are morphing into a political crisis with 
implications across the EU. Finally, Poland represents well the Eastern European stock markets. We will use a fully-fledged $6 \mathrm{X} 6$ BEKK-GARCH model to characterise the fundamental market interactions among these selected European economies in the period of 2016-2017. During this period, the UK experienced important Brexit-related events, such as the announcement of the EU referendum date, the return of the EU referendum result and the invocation of Article 50 of the Treaty on European Union, following the royal assent of the European Union Referendum Act on $17^{\text {th }}$ December 2015. Given the watershed moment of the EU referendum, we further contrast the market interactions by estimating the model in the sample periods of 24/06/2015-23/06/2016 and 24/06/2016-23/06/2017 respectively.

In addition to the derivation of the cross-market information transmissions and causal relationships among the stock markets under the uncertainty of Brexit, we will adopt a couple of advanced time series techniques, namely, volatility spillover accounting of Diebold and Yilmaz (2012) and variance and covariance impulse response functions of Hafner and Herwartz (2006), to extend the investigation within this multivariate setting. Specifically, we will quantify the sizes and identify the signs of the market interactions by estimating the net total volatility spillovers of these individual markets and the net volatility spillovers between these markets and observe how the market interactions have evolved in an extended period of 2015 and 2017. Given that other events or news could have also influenced stock market interactions in the period under study, we will isolate the shocks of Brexit-related events, such as the announcement of the EU referendum date on $21^{\text {st }}$ February 2016, the return of the unexpected referendum result on $24^{\text {th }}$ June 2016 and the invocation of Article 50 of the Treaty on the European Union on $29^{\text {th }}$ March 2017, from the historical data and trace the time patterns of their effects on volatilities and co-volatilities of the markets under study. We will further compare and contrast the impacts of the Brexit-related events with the market 
responses to other major shocks of 2016, in anticipation of identifying the nature of a destabilising event. The other events that will be covered in this study include the announcement by the European Central Bank (ECB) of the stimulus measures to combat deflation in Eurozone in March, the US presidential election in November and the Italian constitutional referendum in December of 2016.

Like Aristeidis and Elias (2018) and Nishimura and Sun (2018), our study makes use of intraday stock prices to capture the market interactions during the period covering the Brexitrelated events. The analysis of the intraday volatility spillovers under such great uncertainty enables a better understanding of the financial market dynamics, given an unprecedented surge in electronic and automated trading over the last few years. However, our paper differs from Aristeidis and Elias (2018) and Nishimura and Sun (2018) in one major way. We estimate the impacts of the Brexit-related events by measuring the differences in the historical market variances or covariances in the presence and absence of the events, as stipulated by Hafner and Herwartz (2006). That is, we acknowledge that other factors might have also impacted market volatilities and co-volatilities in the period under study, but we have no way to control for all of them individually. Instead we isolate the events of our interest respectively and contrast the market variances and covariances in the presence and absence of these events in order to obtain the changes in the market volatilities and covolatilities due to the events. On the contrary, both Aristeidis and Elias (2018) and Nishimura and Sun (2018) implicitly assume that the market behavior before an event, e.g., the EU referendum, differs from that after the event for no other reason than the event per se and gauge the impact of the referendum on the basis of the changes in the market correlations or the differences in the time series plots of the volatility spillover indices before and after the event. This assumption is too restrictive and has been recognized as the main reason why the 
conventional event-study approach produces biased estimates. Hence, our study complements Aristeidis and Elias (2108) and Nishimura and Sun (2018) and contributes to the literature on the impact of Brexit as follows. We firstly isolate and estimate the impacts of the Brexitrelated events on the market interactions by capturing the size, sign and duration of the eventspecific market volatilities and co-volatilities that have not been reported in the literature. Secondly, we contrast the impacts of various shocks and identify the nature of an event that could destabilize the EU institution the most. Taken together, our empirical analysis conveys valuable information to policymakers, practitioners, and financial institutions responsible for designing asset allocation and risk management strategies under the uncertainty of Brexit.

The remainder of the paper is organised as follows. We describe the model and statistical approaches in section 2 and report the empirical results in section 3. Section 4 concludes.

\section{METHODOLOGY}

As we wish to explore in depth how the volatility spillovers among the European stock markets have been influenced by the uncertainty of Brexit, we have chosen the multivariate setting of BEKK-GARCH (Engle and Kroner, 1995), within which we will not only obtain statistical evidence of the market interactions via likelihood ratio tests, but also isolate and gauge the impacts of Brexit-related events on the stock market volatilities and co-volatilities via an impulse response analysis of Hafner and Herwartz (2006). We will also depict the evolution of the stock market interactions under the uncertainty of Brexit through estimating the net total and pair volatility spillovers by the variance decompositions of Diebold and Yilmaz (2012).

\subsection{A VAR(4) - 6×6 BEKK-GARCH model}


The interactions within the six European stock markets are estimated through examining the joint processes relating to their market returns as follows.

$Y_{t}=\alpha+\sum_{p=1}^{4} \Phi_{p} Y_{t-p}+\varepsilon_{t}$

where $\alpha$ is a $6 \times 1$ vector of constants. $Y_{t}$ is a $6 \times 1$ vector of returns over intervals of 30 minutes at time t and $\Phi_{\mathrm{p}}$ are $6 \times 6$ matrices of parameters associated with the lagged returns of 4 periods. In this age of digital information, stock markets should be able to absorb any information sufficiently within two hours after news first appears, hence information under two hours old, i.e., returns of past 4 periods of 30-minute intervals, should be relevant to the determination of market returns. Note that the stock exchanges in the UK, Germany, France, Ireland, Italy and Poland are respectively indexed as 1, 2, 3, 4, 5 and 6 . The random error, $\varepsilon_{t}$, is modelled as ${ }_{t}=H_{t}^{1 / 2} z_{t}$. While $\mathrm{z}_{\mathrm{t}}$ is the $6 \times 1$ random vector, following $\mathrm{E}\left(\mathrm{z}_{\mathrm{t}}\right)=0$ and $\operatorname{Var}\left(\mathrm{Z}_{\mathrm{t}}\right)=\mathrm{I}_{\mathrm{N}}, \mathrm{H}_{\mathrm{t}}$ is a $6 \times 6$ positive definite symmetric matrix, modelled as a function of the lagged cross products of errors and lagged $\mathrm{H}_{\mathrm{t}}$ as follows.

$$
H_{t}=C C+A_{t 1 t_{1}} A+G H_{t 1} G
$$

where $C$ is a $6 \times 6$ lower triangular matrix of constants and $A$ and $G$ are $6 \times 6$ coefficient matrices. We will estimate the VAR-BEKK system using the approximate Quasi Maximum likelihood Estimation (QMLE) method and accommodate the conditional distribution of $\varepsilon_{\mathrm{t}}$ to follow a Student's t distribution in the presence of leptokurtosis.

Given the large number of estimated coefficients, including three sets of coefficient matrices, $\Phi, \mathrm{A}$ and $\mathrm{G}$, in the system, likelihood ration tests will be employed to summarise the existence of the cross-market effects. To gauge the signs or sizes of the cross-market effects or how long these effects require to take place, we will implement the variance 
decompositions of Diebold and Yilmaz (2012) and volatility impulse response function of Hafner and Herwartz (2006).

\subsection{Variance decompositions of Diebold and Yilmaz (2012)}

Diebold and Yilmaz (2012) propose to measure total and directional volatility spillovers within and across markets by computing the forecast error variance decompositions from a generalised VAR framework of Koop, Pesaran and Potter (1996) and Perasan and Shin (1998). The generalised VAR framework ensures that the forecast error variance decomposition is invariant to the ordering of the variables in the system. Like any variance decomposition, it starts with a covariance stationary N-variable VAR(p) model like Eq. (1). In this setting, the variables are realised volatilities, $y_{i}$, of the market returns instead of the market returns, $\mathrm{Y}_{\mathrm{i}}$. By writing the VAR process as a moving average representation with $\mathrm{N} \times \mathrm{N}$ coefficient matrices $\mathrm{B}_{i}$, we obtain the contribution of market $\mathrm{j}$ to market i's F-stepahead generalised forecast error variance as follows.

$$
\theta_{i j}(F)=\frac{\sigma_{j j}^{-1} \sum_{f=0}^{F-1}\left(e_{i}^{\prime} B_{f} \sum e_{j}\right)^{2}}{\sum_{f=0}^{F-1}\left(e_{i}^{\prime} B_{f} \sum B_{f}^{\prime} e_{i}\right)}
$$

where $\mathrm{F}=1,2, \ldots$, and $\sigma_{\mathrm{jj}}$ is the standard deviation of the error term for the jth equation; $\mathrm{e}_{\mathrm{i}}$ is the selection vector with one as the ith element and zeros elsewhere; $\mathrm{B}_{\mathrm{f}}$ is the coefficient matrix B multiplying the f-lagged error vector $\varepsilon$ in the infinite moving average representation of the generalised VAR system and $\Sigma$ is the variance covariance matrix of the error vector in the generalised system.

The proportions of the F-step-ahead error variances in forecasting $y_{i}$ that are due to shocks to $\mathrm{y}_{\mathrm{j}}$ can be defined as volatility spillovers, while the fractions of the F-step-ahead error 8 
variances in forecasting $y_{i}$ that are due to shocks to $y_{i}$ for $i=1,2, \ldots, N$ are own variance shares. Normalising each entry of the variance decomposition matrix by the row sum such that $\sim_{i j}(F)=\frac{i j}{N}(F)$, the net total volatility spillovers, i.e., the difference in spillovers ${ }_{i j}(F)$ $j=1$

transmitted by market $\mathrm{i}$ to all other markets and those received by market $\mathrm{i}$ from all other markets, can be measured by

$S_{i}(F)=\left(\frac{\sum_{\substack{j=1 \\ j \neq i}}^{N} \tilde{\theta}_{j i}(F)}{\sum_{i, j=1}^{N} \tilde{\theta}_{j i}(F)}-\frac{\sum_{\substack{j=1 \\ j \neq i}}^{N} \tilde{\theta}_{i j}(F)}{\sum_{i, j=1}^{N} \tilde{\theta}_{i j}(F)}\right) \times 100$

Similarly, the net pairwise volatility spillover between markets $i$ and $j$ will be

$$
\begin{aligned}
& S_{i j}(F)=\left(\frac{\sim{ }_{j i}(F) \sim_{i j}(F)}{N}\right) 100 \\
& \sim_{i j}(F)
\end{aligned}
$$

We will use the net total volatility spillovers and net pair volatility spillovers to measure the sizes and identify the signs of market interactions in order to supplement the statistical significance obtained through the likelihood ratio tests as described in the previous section.

\subsection{Volatility impulse response functions of Hafner and Herwartz (2006)}

Instead of tracing the responsiveness of market returns in a VAR to unit shocks to each of these variables, Hafner and Herwartz (2006) propose to trace time pattern of the effects of independent shocks on variances and covariances in the BEKK setting. Unlike Diebold and Yimaz (2012) who use the generalised VAR framework to deal with the ordering problem, 
Hafner and Herwartz (2006) employ a Jordan decomposition to decompose variance so that identical and independent shocks can be retrieved from Eq. (2).

In the context of Eq. (2), the symmetric matrix of $H_{t}^{1 / 2}$ is decomposed as:

$H_{t}^{1 / 2}={ }_{t}{ }_{t}{ }_{t}^{1 / 2} \quad{ }_{t}$

where $\Lambda_{t}=\operatorname{diag}\left(\lambda_{1 t}, \ldots, \lambda_{4 t}\right)$ is the diagonal matrix whose components $\lambda_{\mathrm{it}}, \mathrm{i}=1, \ldots, 6$, denote the eigenvalues of $H_{t}$ and $\Gamma_{t}=\left(\gamma_{1 t}, \ldots, \gamma_{6 t}\right)$ is the $6 \times 6$ matrix of the corresponding eigenvectors. Hence the independent shocks are defined as

$z_{t}=H_{t}{ }^{1 / 2}{ }_{t}$

Under the hypothesis of a non-Gaussian distribution, $\mathrm{z}_{\mathrm{t}}$ is uniquely defined and may be treated as shocks from the past that could affect each of the markets in the future. Therefore, a volatility impulse response function can be defined as the difference between the expectation of volatility conditional on an initial specific shock $\mathrm{z}_{0}$ and the observed history ( $\left.\mathrm{I}_{\mathrm{t}-1}\right)$ and the baseline expectation that only conditions on history:

$V_{t}\left(z_{0}\right)=E\left[\operatorname{vech}\left(H_{t}\right) \mid I_{t 1}, z_{0}\right] \quad E\left[\operatorname{vech}\left(H_{t}\right) \mid I_{t 1}\right]$

That is, $\mathrm{V}_{\mathrm{t}}\left(\mathrm{z}_{0}\right)$ traces only the impacts of the identical and independent shock components of zo, e.g., the unexpected result of the EU referendum in our study, on the t-step ahead conditional variance-covariance matrix components. The implementation of the variance impulse response functions is detailed in appendix 1 . We will use the impulse response functions to gauge the size and persistence of the impacts of Brexit-related events on market volatilities and co-volatilities.

\section{Empirical analysis}




\subsection{Data and diagnostic checks on the multivariate model}

This paper works on six European stock market indices, namely, FTSE100 of the UK, DAX of Germany, CAC40 of France, ISEQ20 of Ireland and FTSEMIB of Italy and WIG20 of Poland, during the course of 2015-2017. The data of the indices, retrieved from Bloomberg, are at 30-minute intervals during daily trading hours. Note that all the stock markets open and close at the same Greenwich Mean Time, synchronising information content embedded in the market indices. We derive returns by taking the first differences of the natural logarithm of the market indices and omit the overnight returns, resulting in 16 data points for each trading day. Descriptive statistics of the intraday returns under the uncertainty of Brexit are reported in Table 1. During the periods under study, the average market returns of 30-minute intervals are understandably small, while the standard deviations are relatively large. Overall the stock markets on the European continent fluctuate more than those in the UK and Ireland across periods. The Jarque-Bera statistics reject the null hypothesis that the returns are normally distributed for all cases. The presence of leptokurtosis requires us to adopt t-distribution and Quasi Maximum Likelihood estimation in our analysis.

[Table 1 is about here.]

We firstly estimate a VAR(4)-6x6 BEKK-GARCH using the sample period of 04/01201621/10/2017 to observe how the stock markets interacted under the uncertainty of Brexit. Then we contrast the market interactions in the pre-referendum period of 24/06/2015 23/06/06/2016 and in the post-referendum period of 24/0/2016 - 23/06/2017 respectively. The three multivariate GARCH models are successfully estimated, as convergence is achieved in all cases. Moreover, in each case, altogether 244 parameters are estimated and the estimated degree of freedom parameter of the student's t distribution is about 6 at the significance level of $1 \%$. As these estimates are only the basis for the subsequent likelihood 
ratio tests, we refrain from reporting them to save space. Nonetheless all these unreported results of the VAR(4)-6x6 BEKK-GARCH models are available on request.

Before we summarise the cross-market effects through the likelihood ratio tests on the basis of these BEKK-GARCH estimates, we carry out diagnostic checks on the estimated VAR(4)$6 \times 6$ BEKK-GARCH $(1,1)$ models respectively. On the basis of the diagnostic results presented in Table 2, we note that the GARCH models are overall well specified. Firstly, the mean equations are appropriate. In 2016-2017, the multivariate Q statistics confirm that the error terms are not auto-correlated up to 12 lags, although the univariate Q statistics suggest autocorrelation of the error terms in the cases of UK and Germany individually. In the subperiods, the multivariate $\mathrm{Q}$ statistics also confirm non-autocorrelation in the error terms, while the univariate Q statistics suggest autocorrelations in the errors for the UK in the prereferendum period and for Germany and Ireland in the post-referendum period. Secondly, in all cases, the eigenvalues of the estimated $A \quad A+G \quad G$ are less than one, confirming that variances and covariances are stationary. The stationary variances and covariances permit the analysis of volatility and co-volatility impulse responses that we will implement subsequently in the sample period of 2016 - 2017. Furthermore, the eigenvalues of all but Poland are close to one, indicating a high level of persistence in volatility transmissions across five of the six markets under study. The results of the likelihood ratio tests, as reported in Panels B of Table 2 , further validate the specification of this VAR(4)-6×6 BEKK-GARCH model in all periods. On the basis of the $\chi^{2}$ statistics of $726.81,1297.1$ and 255.06 , we can reject the null hypothesis that the mean equation contains only a constant, confirming that VAR(4) is more appropriate as a mean equation in any of the sample periods. Secondly, at $\chi^{2}(180)=1240.54$, 2558 and 616.99, we can reject the null hypothesis that the coefficients of the covariance equations are zero simultaneously $\left(\mathrm{a}_{\mathrm{ij}} \mathrm{a}_{\mathrm{ji}}=\mathrm{g}_{\mathrm{ij}} \mathrm{g}_{\mathrm{ji}}=0, \mathrm{i} \neq \mathrm{j}\right)$ in any of the sample periods. Rejection 
of this null hypothesis indicates that the conditional variances in the system are not independent, supporting the estimation of the cross-market interactions using a systematic approach like this $6 \times 6 \mathrm{GARCH}-\mathrm{BEKK}$ model, as opposed to univariate GARCH models, for the six markets under study. At $\chi^{2}(60)=468.89,362,73$ and 296.79 , we can reject the null hypothesis that the off-diagonal coefficients in matrices A and $G$ are simultaneously zero $\left(a_{i j}=g_{i j}=0, i, j=1,2,3,4\right.$, and 6 and $\left.i \neq j\right)$, supporting the modelling of the six markets as a fullyfledged BEKK, as opposed to a diagonal BEKK, in all periods. Overall the VAR(4)-6×6 BEKK-GARCH $(1,1)$ model is adequate and appropriate for the purpose of the intended analyses.

[Table 2 is about here.]

\subsection{Empirical results}

\subsubsection{Evidence of spillovers across markets}

The information flows, captured by the likelihood ratio tests on the off-diagonal elements in the matrices of $\Phi, \mathrm{A}$ and $\mathrm{G}$, can suggest return and volatility spillovers between markets. In Table 3, we report the results of the likelihood tests and identify the information flows in 2016-2017 by contrasting statistical significance of $\chi^{2}$ statistics within each row of Table 3 . In all six stock markets, we can reject null hypotheses that the returns and volatilities of the individual markets do not affect those of the other five markets simultaneously, as evident by $\chi^{2}(30)=76.35,123.81,271851,60.09,130.83$ and 51.68, and that the returns and volatilities of individual markets are not affected by those of the other five markets jointly, on the basis of $\chi^{2}(30)=103.87,146.80,106.74,101.38,49.28$ and 113.39. Rejection of these hypotheses suggests bi-directional information transmissions or spillovers between each of the individual markets and the other five markets as a whole. We also note statistically significant bidirectional relationships between six out of 15 pairs of markets that could have formed 
among the six stock markets under study. Specifically, there are bi-directional return and volatility spillovers between the UK and France, between Germany and France and Italy, between France and Italy and Poland and between Italy and Poland. The remaining pairs of markets feature uni-directional spillovers, given that only one of paired $\chi^{2}$ statistics is statistically significant in each of the remaining rows of Table 3. For instance, there is unidirectional spillover from the UK to Germany, given that we can reject null hypothesis that the UK market does not affect the German market at $\chi^{2}=29.16$ and cannot reject the null hypothesis that the UK market is not affected by the German market at $\chi^{2}=10.06$. Overall the information transmissions from the other individual markets to the UK are more statistically significant than those from the UK to these individual markets in 2016-2017. As a contrast, information transmissions from France to the other markets are more statistically significant than the reverse transmissions in this uncertain period of 2016-2017.

[Table 3 is about here.]

To contrast the interactions between the UK and the other EU stock markets before and after the EU referendum on $23^{\text {rd }}$ June 2016, we summarise the results of the likelihood ratio tests for the two sub-periods in Table 4. The full sets of the results of the likelihood ratio tests for the sub-periods can be found in Tables 1 and 2 of the manuscript's supplementary material. It is noted that, in the period of 24/06/2015 - 23/06/2016, the $\chi^{2}$ statistics in column 3 are all highly statistically significant in the panel about FTSE100 and support the rejection of the null hypotheses that there is no information transmission from the UK to the other markets jointly or individually. Meanwhile, the $\chi^{2}$ statistics in column 6 cannot completely support the rejection of the null hypotheses that there is no information transmission from the other EU markets to the UK individually. It seems that volatilities spill from the UK market to the French, Irish and Polish markets uni-directionally prior to the EU referendum. After the EU 
referendum, the UK's influence over the EU markets diminishes, as evident by the reduced number of statistically significant $\chi^{2}$ in the panel about FTSE100 of column 3 . It seems that the UK only affects the Irish market, while it is affected by the French and Italian markets in the sub-period of 24/06/2016-23/06/2017. While keeping the bi-directional relationship with the Germany stock market, there is no more connection between the UK and the Polish market post-the EU referendum.

[Table 4 is about here.]

\subsubsection{Accounting of volatility spillovers}

While the estimates of the VAR(4)-6×6 BKK-GARCH models help derive the statistical significance of the cross-market interactions in the form of information transmissions or spillovers, they cannot quantify the sizes of the market interactions. In order to capture the sizes as well as signs of the interactions across the markets under study, we follow Diebold and Yilmaz (2012) to estimate dynamic directional volatility spillovers by decomposing volatility forecast error variances of VAR(4) using 200-period rolling samples and obtaining time-varying net volatility spillovers from 2015 to 2017. To be consistent with the analysis by the likelihood ratio tests in the previous section, we are interested in, respectively, net volatility spillovers between each of the stock markets and the other five markets as a whole, denoted as net total spillovers, and net volatility spillovers between each pair of markets, denoted as net pair spillovers.

[Figure 1 is about here.]

Figure 1, plotting the rolling-sample intraday net total volatility spillovers, appears to suggest that the UK stock market, with substantial positive net total volatility spillovers, was a dominant net information emitter to the other markets in 2015. However, the positive net total 
spillovers from the UK to other markets have drastically decreased in magnitude, since the campaign for the EU referendum started in January 2016. In 2016, the UK appears to be a net information receiver. Since then, the UK has positioned itself as a non-dominant player in the European stock markets, alternating between being a net information emitter and receiver. On the contrary, since January 2016, the French market has become a net information emitter and the German stock market has tended to transmit information to other markets on many occasions too. It seems that France and Germany, albeit to a less extent in the latter, are confirmed to replace the UK as influential players among the six European stock markets under the uncertainty of Brexit.

[Figure 2 is about here.]

Figure 2, plotting the rolling-sample net pair volatility spillovers, appears to confirm overall that the UK exerts great influences on all the other five markets in 2015, but its influences on these markets, especially those in Germany and France, drastically reduce in 2016 and 2017. Although the uni-directional spillovers from the UK to the individual markets, such as Germany and Poland, in 2016-2017 are found to be statistically significant by the likelihood ratio tests, the net pair volatility spillovers suggest that the uni-directional influences from the UK are generally small in magnitude. On the contrary, France appears to exert influences on Ireland, Italy and Poland persistently, given its mostly positive net pair spillovers in all three cases. Similarly, with positive net pair volatility spillovers on more occasions, Germany maintains its influences on Ireland, Italy and Poland throughout 2015 and 2017. It is interesting that the French stock market dominates the German stock market, as evident by the more frequent occurrence of negative net spillovers in the net pair spillovers from Germany to France. 


\subsubsection{Tracing responses to Brexit-related events}

In this section, we use the technique of Hafner and Herwartz (2006) to isolate the impacts on the market interactions of Brexit-related shocks, such as the announcement of the EU referendum date, the return of the EU referendum result and the invocation of Article 50 of the Treaty on the European Union.

On Saturday 20th February 2016, Prime Minister David Cameron announced that the UK's in/out referendum would be held on $23^{\text {rd }}$ June 2016. His cabinet colleagues started to come out and campaign formally in favour of or against Britain's membership. As the stock exchanges did not open until Monday 22nd February, we set the initial shock at 08:30 (the first observation) on $22^{\text {nd }}$ February and obtain the variance responses to the shock over time. Note that we re-scale the response time horizons from a step of 30 minutes to a step of one trading day and the variance changes over 15-minute intervals to daily variance changes. This re-scaling is applied to all subsequent variance and covariance response impulse analyses. In panel A of Figure 3, we plot the daily variance percentage changes in response to the announcement of the EU referendum date against the response time horizons. Firstly, the stock markets respond differently to the shock of the announcement of the EU referendum date. While it increases gradually and peaks around day 5 in the UK and Germany, market volatility increases instantaneously in Ireland. On the contrary, the shock of the announcement of the EU referendum date causes the market volatilities in France and Poland to change from an instantaneous decrease to a rapid increase within two days, while it takes about eight days for the market volatility in Italy to change from an instantaneous decrease to an increase. Secondly, the shock of the announcement has exerted relatively small impacts on the expected conditional variances for all the markets under study. The largest change in onestep-ahead market volatility is observed to be slightly over $3 \%$ in the case of Germany. The 
time lag between the announcement of the referendum date (Sunday) and the opening of the stock markets (the following Monday) might have allowed the markets to digest the news and price the risk fully, limiting changes to the market volatilities to small extents. Finally, the impacts, albeit small in magnitude, tend to decrease gradually and do not disappear until the $25^{\text {th }}$ day for the UK, Germany and Ireland, the $30^{\text {th }}$ day for France and the $35^{\text {th }}$ day for Italy after the initial shock. The persistence of these impacts is consistent with the prediction by the eigenvalues of $A \quad A+G$ Gin Table 2. In the case of Poland, the market response is negligible in magnitude and duration, consistent with its low eigenvalues reported in Table 2.

[Figure 3 is about here.]

On $23^{\text {rd }}$ June 2016, Britain went to the polls to answer the questions: "Should the United Kingdom remain a member of the European Union or leave the European Union?' On $24^{\text {th }}$ June 2016, the world awoke to the unexpected result of the EU referendum: The majority of the UK voters voted to leave the EU. The UK Prime Minister David Cameron resigned. The realised volatility jumped by $143 \%$ in the UK stock market at $8: 30$ am on $24^{\text {th }}$ June. In panel B of Figure 3, the volatility impulse response functions show that the shock of the EU referendum result increases the expected conditional variances across all markets. The impacts are instantaneous and substantial at $160 \%$ in the cases of the UK and Italy and at $30 \%$ in the case of Poland. The positive impacts of the shock on the market volatilities in Ireland and France continue to increase and peak at $40 \%$ on day 3 and day 7 respectively. Even Germany experiences a rise in daily market volatility by as high as $20 \%$ at the peak. In all cases but Poland, once more, the impacts of the shock of the EU referendum result are persistent and do not dissipate until the $25^{\text {th }}$ day, at the earliest in the case of UK, after the initial shock. In the case of Italy, the upward pressure on the conditional variance lasts well over 40 days. 
The UK Prime Minister Theresa May invoked Article 50 of the Treaty on the European Union at 12:20 on $29^{\text {th }}$ March 2017, formally starting the process of the UK's departure from the EU. Article 50 gives the UK and the EU two years to reach agreement, so unless both sides agree to extend the deadline for talks, the UK will leave on $29^{\text {th }}$ March 2019 . The stock market responses to the invocation of Article 50 since 12:30 of $29^{\text {th }}$ March 2017 are plotted in Panel $\mathrm{C}$ of Figure 3. Note that the initial percentage changes are estimated on the basis of four trading hours on $29^{\text {th }}$ March. It seems that the invocation has decreased instantaneously the conditional variances across all markets. The magnitude of impacts is indeed very small, at $0.7 \%$ for Italy and under $0.2 \%$ for the UK. Although they are minimal, the impacts are persistent in the cases of Germany and France.

As the focus of this study is market interactions, we now examine how the Brexit-related events impact the co-volatilities of the stock markets. The covariance impulse response functions are plotted in Figure 4. Panel A of Figure 4 shows that the announcement of the referendum date has exerted a downward pressure, albeit of a small magnitude, on all the expected conditional covariances instantaneously. As time goes by, the negative impacts of the announcement of the EU referendum date turn positive, causing market co-volatilities to increase in all cases. The co-volatility between Germany and France peaks on day 5 at nearly $3 \%$. It is interesting to see that the move by the UK government affects the co-movements between Germany, France and Italy more than the UK's co-movements with these Eurozone markets, both in terms of magnitude and duration.

[Figure 4 is about here.]

Panel B of Figure 4 shows that the unexpected result of the EU referendum exerts diverse impacts on the conditional covariances. While it negatively impacts the co-volatilities 
associated with Italy initially, the shock exerts positive impacts instantaneously on the comovements between the UK, Germany, France, Ireland and Poland. In the cases of positive impacts, the greatest changes are observed in the covariances associated with the UK, as expected. Specifically, in response to the shock of the unexpected referendum result, the onestep-ahead expected conditional covariance between the UK and Poland increases by 50\% instantaneously, while the co-volatility between the UK and Ireland becomes the highest on day 2. The conditional covariances between the UK and Germany and France also increase instantaneously and substantially at about $30 \%$ in response to the shock. On the other hand, the unexpected EU referendum result exerts sharp negative impacts (up to 60\%) initially on the co-movements associated with Italy. However, all the negative impacts decrease very quickly and become positive by day 4 , at the latest, after the initial shock. By day 8 , the impacts peak and force the conditional covariances to increase by a range from about $20 \%$ (between the UK and Italy) to $45 \%$ (between France and Italy). Moreover, the impacts of the unexpected EU referendum result on the expected conditional covariances associated with Italy are highly persistent and will not disappear until the $40^{\text {th }}$ day after the initial shock. Panel $\mathrm{C}$ of Figure 4 shows that the invocation of Article 50 decreases all the co-volatilities instantaneously and the largest decreases are observed for the changes to the covariances associated with Italy. However, even the highest change to the covariance between Italy and France is indeed minimal, at $0.5 \%$, in terms of magnitude.

We have also estimated variance and covariance impulse responses of the six stock markets to other major events, such as the adoption of the stimulus measures by the European Central Bank to combat deflation in Eurozone on $10^{\text {th }}$ March 2016, the US election on $8^{\text {th }}$ November 2016 and the Italian constitutional referendum on $4^{\text {th }}$ December 2016 . The results are reported in Figures 1 and 2 of this paper's supplementary material. We note that none of the 
events has exerted any impact greater than that of the EU referendum on the conditional variances and covariances of the markets under study. For instance, the announcement of the adoption of the stimulus measures by the ECB exerts negative impacts on all conditional variances and covariances, either instantaneously or gradually, reducing the expected conditional variances by a range from $1.5 \%$ (for Poland) to 5\% (for Germany) and decreasing the conditional covariance between Germany and France by the highest rate of $3.5 \%$. As unexpected as the EU referendum result, Mr Trump was elected as the $45^{\text {th }}$ president of the US on $8^{\text {th }}$ November. The election result also exerts positive impacts on the conditional variances of the market indices instantaneously on $9^{\text {th }}$ November, but its impacts are generally smaller in magnitude than those of the EU referendum result. While the volatility of WIG20 hardly changes, the expected conditional variance of DAX is observed to instantaneously rise by the largest degree of around 20\%. Similarly, the changes in the expected conditional covariances in response to the unexpected election result are also smaller, compared with those in response to the EU referendum result. For instance, the highest changes are observed to be around $15 \%$ and they are associated with conditional covariances between DAX, CAC40 and FTSEMIB. On Sunday $4^{\text {th }}$ December, Italy held a referendum on the constitutional reform. On Monday $5^{\text {th }}$ December, positive impacts are instantaneously exerted on the conditional variances of all market indices. As expected, the volatility of FTSEMIB is substantially affected, increasing by $60 \%$ instantaneously in response to the shock. Similarly, as expected, the Italian constitutional referendum impacts substantially the covariances associated with Italy, especially those between Italy and Germany, France and Ireland in Eurozone. However, the impacts exerted by the Italian referendum on the rest of markets are not so strong as those exerted by the unexpected EU referendum result either. 


\subsubsection{Volatility spillovers in the presence of the US}

The analyses in the previous sections serve well the purpose of contrasting dynamic interactions between the individual European stock markets. Due to the limited overlap in the daily trading hours between the stock markets in the US and Europe, we cannot include the US market in the multivariate GARCH models that are estimated using intraday data. To address the concerns about the limited representation of the European stock markets as well as the omission of the US in the GARCH system, we now repeat the above analyses by using the daily data of FTSE100, S\&P500, Euro STOXX 50 and STOXX Eastern Europe 300 over 2016-2018. The EURO STOXX 50 Index is Europe's leading blue-chip index for the Eurozone and covers 50 stocks from 11 Eurozone countries: Austria, Belgium, Finland, France, Germany, Ireland, Italy, Luxembourg, the Netherlands, Portugal and Spain. With a fixed number of 300 components, the STOXX Eastern Europe 300 Index represents large, mid and small capitalisation companies across 18 countries of the Eastern European region: Bulgaria, Croatia, Cyprus, Czech Republic, Estonia, Greece, Hungary, Latvia, Lithuania, Macedonia (FYROM), Poland, Romania, Russia, Serbia, Slovak Republic, Slovenia, Turkey and Ukraine. Hence by including these two indices in the GARCH system, we cover the majority of the stock markets in Europe. With a lower frequency of the daily data, the sample period since the campaign for the EU referendum is extended to 2016-2018 to increase the degrees of freedom. In this section, the basic model is diagnosed by likelihood ratio tests to be a VAR(1)-4x4 BEKK GARCH. To save space, we report the results of cross-market relationships and the impacts of the Brexit-related events on the market co-volatilities in this $4 \times 4$ setting in Figures 3 and 4 of the manuscript's supplementary material.

The results firstly show that the stock markets in Europe are more correlated with each other than they are with the US market. The correlation between the UK and Eurozone is the 
highest in 2016-2018, consistent with the proposition of Gravity model that the amount of interaction between two markets is inversely proportional to their distance. Secondly, the US market does not influence the stock markets in Europe as much as we expected. The US is either a net information receiver or a negative transmitter on many occasions in the sample period of 2016-2018. On the contrary, the UK is a net information transmitter to the US and Eastern Europe on more occasions in this period under the uncertainty of Brexit. Furthermore, the UK's influence on Eurozone has been decreasing since the government invoked Article 50 of the Treaty on European Union in March 2017. The UK became a net information receiver from Eurozone in 2018 when its government was engaged in negotiation with the EU on the terms of Brexit. These results of net spillovers are consistent with those we obtained from the system in the absence of the US in section 3.2.2.

The impacts of the Brexit-related events on the market co-volatilities in this $4 \times 4$ setting are traced too. It seems that the announcement of the EU referendum date and the return of the EU referendum result increase the market co-volatilities instantaneously, while the invocation of Article 50 decreases them instantaneously. As expected, the response patterns are more streamlined, given that two of the indices are aggregated across individual markets. The unexpected EU referendum result impacts the market co-movements to the greatest extent, while the invocation of Article 50 affects the co-volatilities most persistently, well beyond 50 days in the cases of covariances associated with Eastern Europe and Eurozone. These results are qualitatively similar to those obtained from the GARCH in the absence of the US market in section 3.2.3. Hence, the results from this section can serve as evidence of robustness for the market interactions obtained from the previous sections.

\section{CONCLUSION}


In this paper we document the interaction dynamics across six European stock markets in 2015-2017. Using a VAR(4)-6×6 BEKK-GARCH model and a series of likelihood ratio tests, we obtain the statistical evidence of spillovers amongst the European stock markets under the uncertainty of Brexit and contrast the market interactions before and after the EU referendum. We supplement the statistical significance of the market interactions with sizes and signs gauged and identified through estimating the net total and pair volatility spillovers. Lastly, we isolate the impacts of some Brexit-related events on market volatilities and co-volatilities and contrast them with those of other major events in the course of 2016.

Although the UK is a net volatility transmitter to the other five markets in 2015, its influence over these markets has drastically decreased since the EU referendum in June 2016. The UK's influence over these markets does not seem to recover in 2017 when the business and financial sectors are uncertain about what post-Brexit trade agreement will be like between the UK and the EU. While it increases volatilities of all markets under study, the unexpected result of the EU referendum exerts diverse instantaneous impacts on market interactions, increasing or decreasing market co-movements. However, the duration of the diverging market co-movements is as short as approximately five days, making it not feasible for risk diversification but speculation. Although the ambivalent markets adjust rather quickly and synchronise their movements by day 5, the impacts of the unexpected EU referendum result on market co-volatilities continue to be substantial and persist. Indeed the Brexit decision that threatens the institutional stability of the EU exerts the greatest and most diverse instantaneous impacts on the stock market interactions, compared with other major events in the course of 2016. It is likely that the trade agreement now under negotiation between the UK and the EU for resolution may as well impact the dynamics between markets diversely and persistently. 
Acknowledgment

We would like to thank the editor and two anonymous referees for their highly constructive comments which make this paper more valuable. The usual disclaimer applies.

\section{References}

Aristeidis, S. and K. Elias. 2018. Empirical analysis of market reactions to the UK's referendum results - How strong will Brexit be? Journal of International Financial Markets, Institutions and Money 53, 263-286.

Belke, A., I. Dubova and T. Osowski. 2018. Policy uncertainty and international financial markets: the case of Brexit. Applied Economics 50, 3752-3770.

Bloom, N. 2009. The impact of uncertainty shocks. Econometrica 77, 623-685.

Burdekin, R., E. Hughson and J. Gu. 2018. A first look at Brexit and global equity markets. Applied Economics Letters 25 (2), 136-140

Diebold, F. X., and K. Yilmaz. 2009. Measuring financial asset return and volatility spillovers with application to global equity markets. Economic Journal 119, 158-171.

Diebold, F. X., and K. Yilmaz. 2012. Better to give than to receive: Predictive directional measurement of volatility spillovers. International Journal of Forecasting 28, 57-66.

Engle, R., and K. Kroner. 1995. Multivariate simultaneous generalized ARCH. Econometric Theory 11, 122-150.

Forbes, K. J., and R. Rigobon. 2002. No contagion, only interdependence: Measuring stock market comovements. Journal of Finance 57, 2223-2261.

Hafner, C. M., and H. Herwartz. 2006. Volatility impulse responses for multivariate GARCH models: an exchange rate illustration. Journal of International Money and finance 25, 719740 .

Hosoe, N. 2018. Impact of border barriers, returning migrants, and trade diversion in Brexit: Firm exit and loss of variety. Economic Modelling 69, 193-204.

Jackson, K., and O. Shepotylo. 2018. Post-Brexit trade survival: Looking beyond the European Union. Economic Modelling 73, 317-328.

Koop, G., M. Pesaran, and M. Potter. 1996. Impulse response analysis in nonlinear multivariate models. Journal of Econometrics 74, 119-147.

Nishimura, Y. and B. Sun. 2018. The intraday volatility spillover index approach and an application in the Brexit vote. Journal of International Financial Markets, Institutions and 
Money 55, 241-253.

Pesaran, M. H., and Y. Shin. 1998. Generalized impulse response analysis in linear multivariate models. Economics Letters 58, 17-29.

Ramiah, V., H. Pham and I. Moosa. 2017. The sectoral effects of Brexit on the British economy: early evidence from the reaction of the stock market. Applied Economics 49 (26), 2508-2514.

Samitas, A., S. Polyzos, C. Siriopoulos. 2018. Brexit and financial stability: An agent-based simulation. Economic Modelling 69, 181-192.

Wallace, T., and S. P. Chan. 2016. Why Italy's banking crisis will shake the Eurozone to its core. The telegraph, July 16. http://www.telegraph.co.uk/business/2016/07/16/why-italysbanking-crisis-will-shake-the-eurozone-to-its-core/

\section{Appendix 1: The implementation of impulse response functions of Hafner and Herwartz (2006)}

Given that a volatility impulse response function is defined as the difference between the expectation of volatility conditional on an initial specific shock $\mathrm{z}_{0}$ and the observed history $\left(\mathrm{I}_{\mathrm{t}-1}\right)$ and the baseline expectation that only conditions on history:

$$
V_{t}\left(z_{0}\right)=E\left[\operatorname{vech}\left(H_{t}\right) \mid I_{t 1}, z_{0}\right] \quad E\left[\operatorname{vech}\left(H_{t}\right) \mid I_{t 1}\right]
$$

we put the BEKK estimates of Eq. (2) into a VECH form and obtain the following 1-step ahead VIRF

$$
V_{1}\left(z_{0}\right)=A\left\{\operatorname{vech}\left(H_{0}^{1 / 2} z_{0} z_{0}^{\prime} H_{0}^{1 / 2}\right) \quad \operatorname{vech}\left(H_{0}\right)\right\}=A D_{N}^{+}\left(\begin{array}{lll}
H_{0}^{1 / 2} & \left.H_{0}^{1 / 2}\right) D_{N} \operatorname{vech}\left(z_{0} z_{0}^{\prime}\right. & I_{N}
\end{array}\right)
$$

where $\mathrm{A}$ is the coefficient matrix obtained from the vech representation of Eq. (2), $\mathrm{H}_{0}$ is the conditional variance-covariance matrix at time $0, \mathrm{D}_{\mathrm{N}}{ }^{+}$and $\mathrm{D}_{\mathrm{N}}$ denote the Moore-Penrose inverse and duplication matrices respectively, and is the Kronecker Tensor product.

For any $\mathrm{t} \geq 2$, the VIRF is

$$
V_{t}\left(z_{0}\right)=(A+G)^{t 1} A D_{N}^{+}\left(H_{0}^{1 / 2} \quad H_{0}^{1 / 2}\right) D_{N} \operatorname{vech}\left(z_{0} z_{0}^{\prime} \quad I_{N}\right)=(A+G)^{*} V_{t 1}\left(z_{0}\right)
$$


Figure 1 Net total spillovers estimated by variance decompositions, 2015-2017
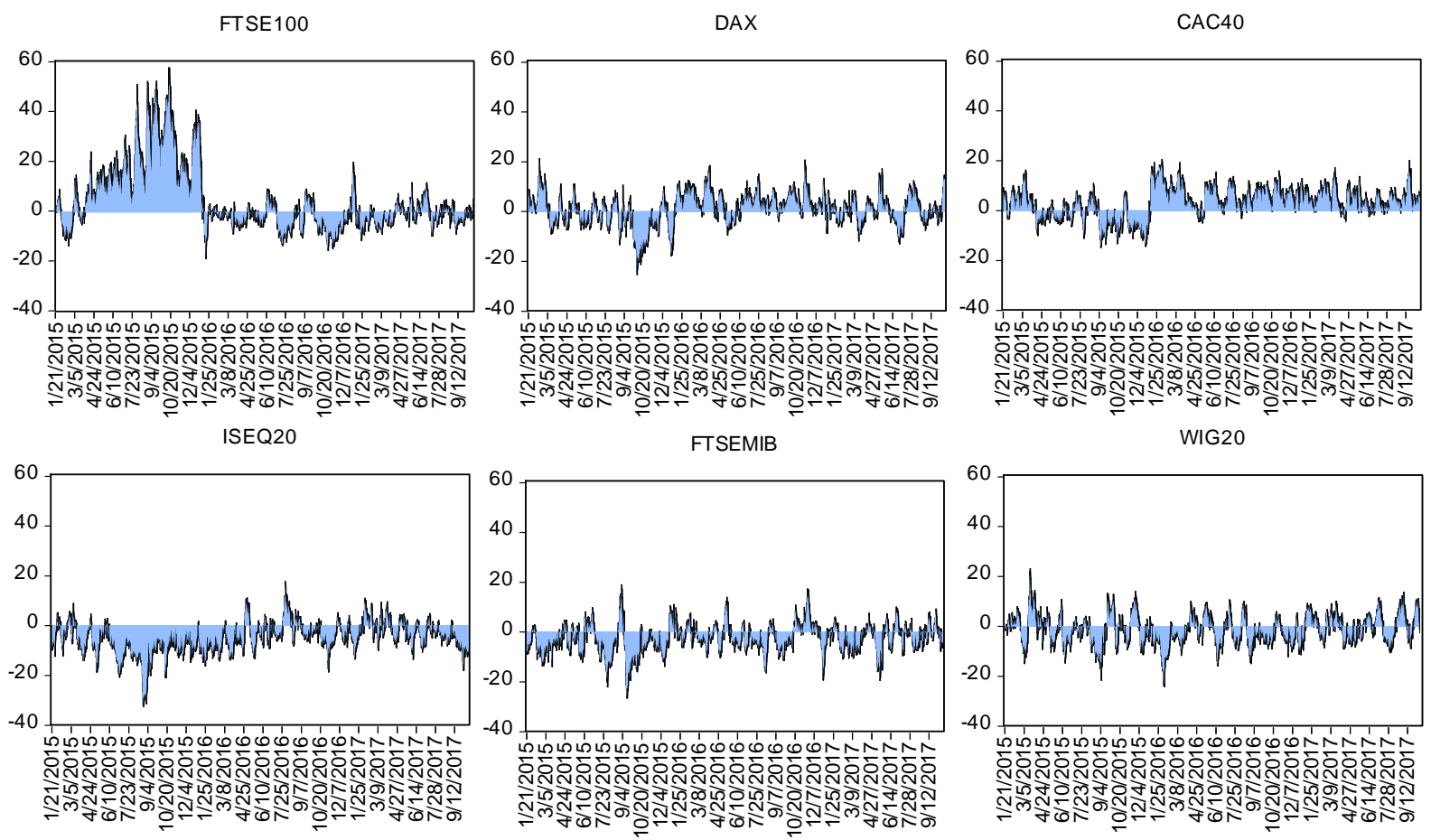
Figure 2 Net pair spillovers estimated by variance decompositions, 2015-2017

FTSE100 - DAX

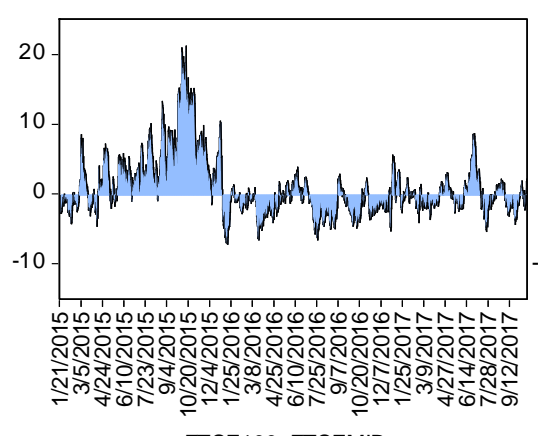

FTSE100-FTSEMIB

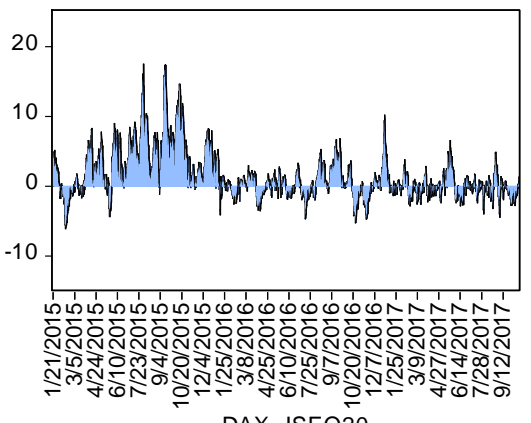

DAX - ISEQ20

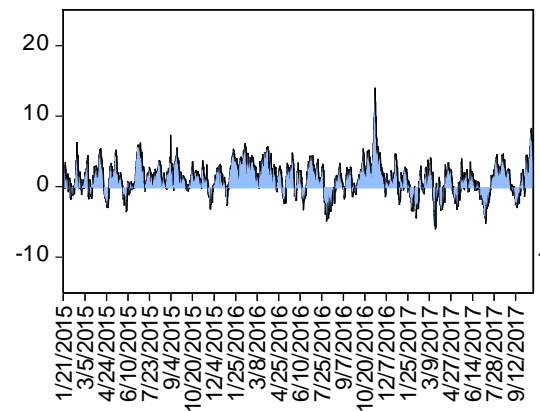

CAC40 - ISEQ20
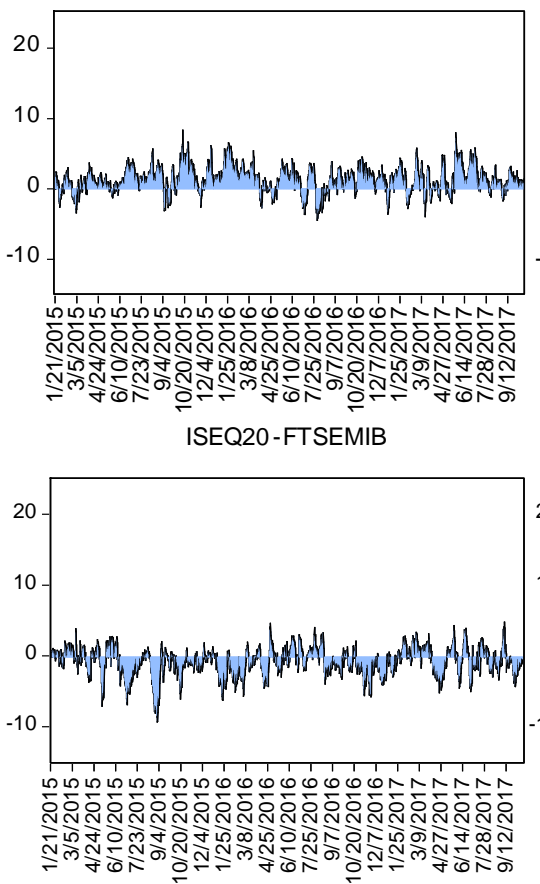

FTSE100 - CAC40

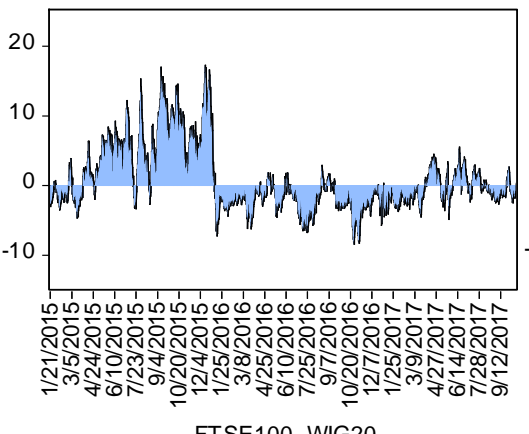

FTSE100 - WIG20

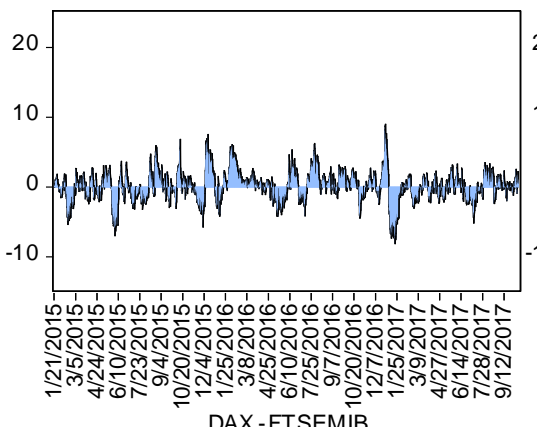

DAX-FTSEMIB

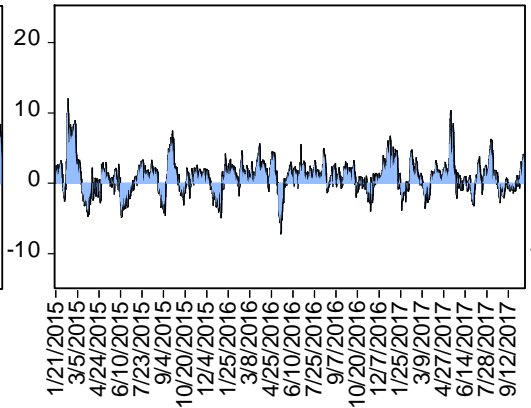

CAC40 - FTSEMIB
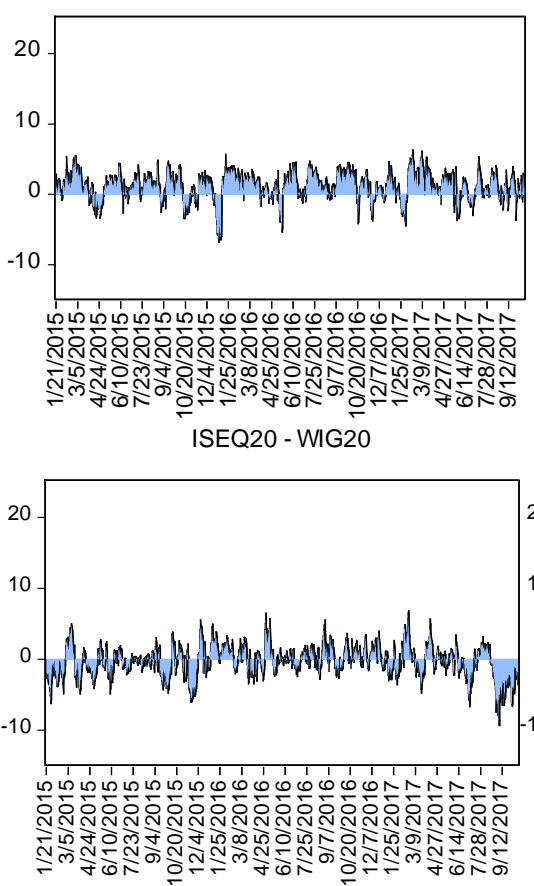

FTSE100 - ISEQ20

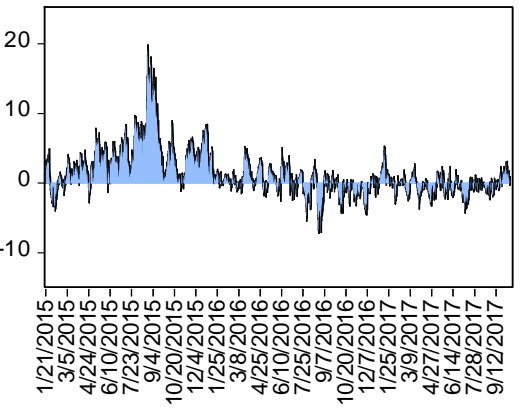

DAX - CAC40

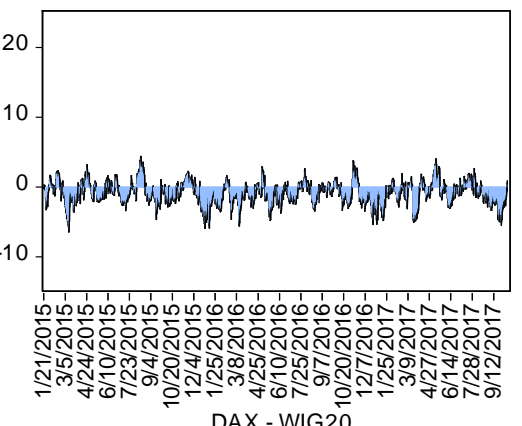

DAX - WIG 20

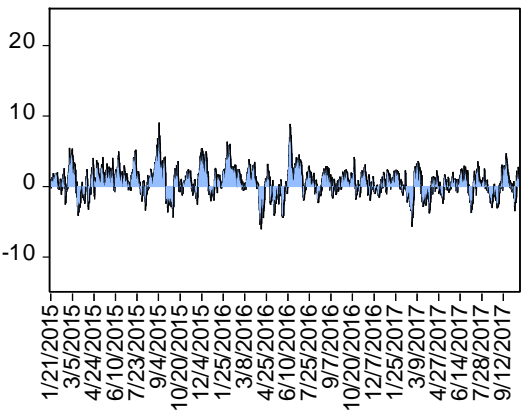

CAC40 - WIG20
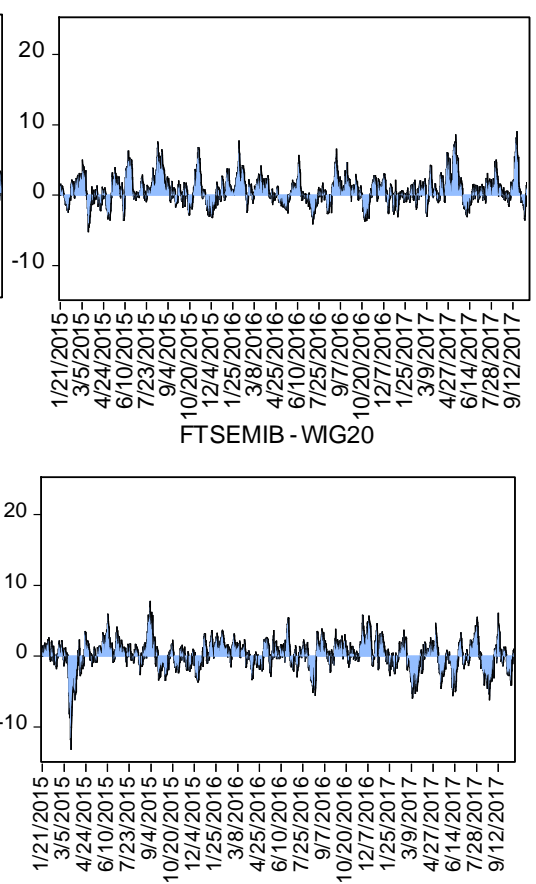
Figure 3 Variance impulse response functions of Brexit-related events

A: The announcement of the EU referendum date on $21^{\text {st }}$ February 2016
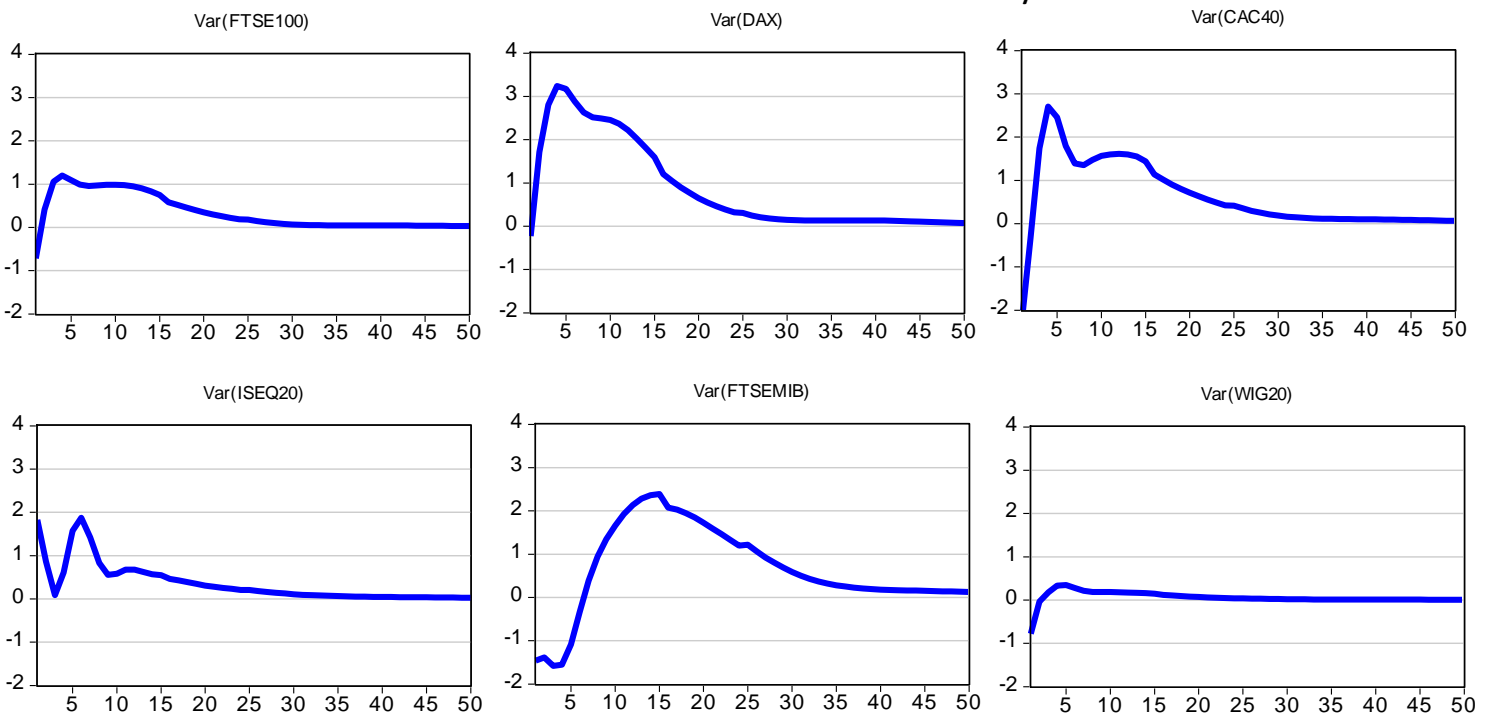

B: The return of the EU referendum result on $24^{\text {th }}$ June 2016

$\operatorname{Var}($ FTSE100)

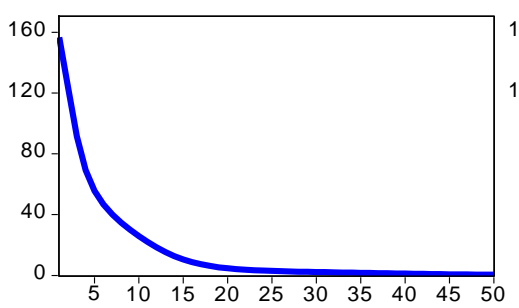

Var(ISEQ20)
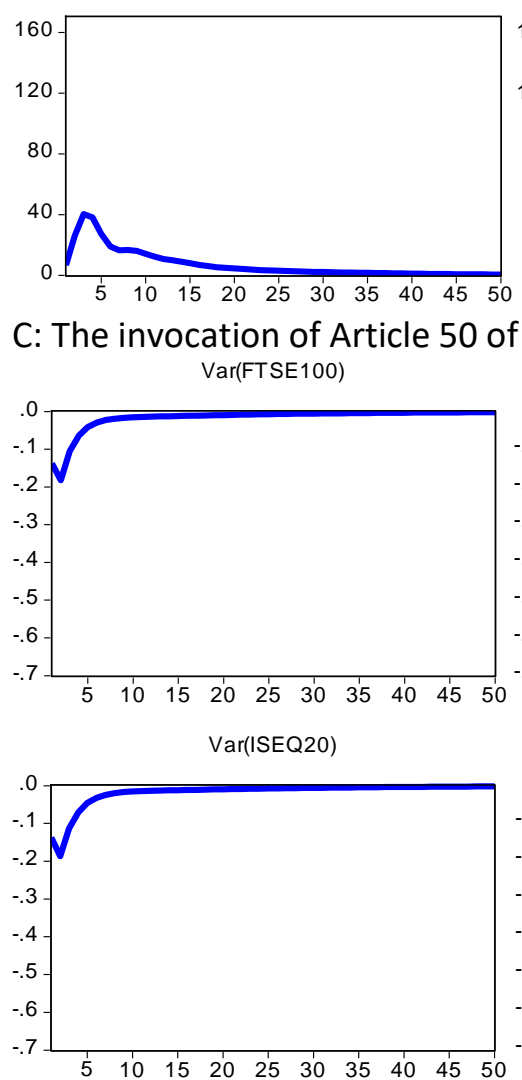

$\operatorname{Var}(\mathrm{DAX})$

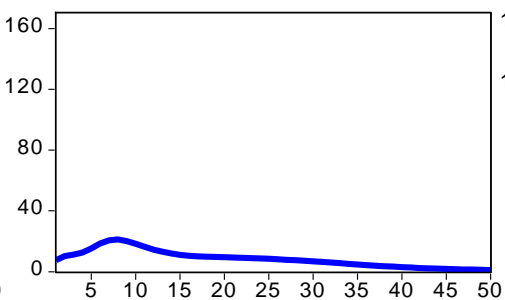

$\operatorname{Var}($ FTSEMIB $)$

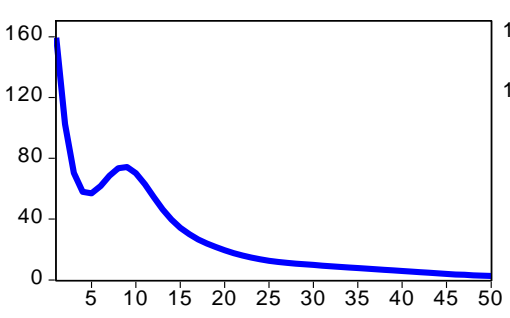

$\operatorname{Var}(\mathrm{DAX})$

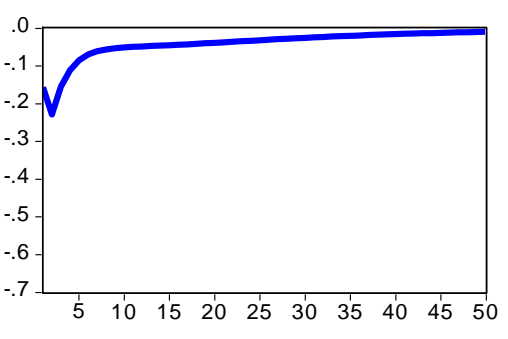

$\operatorname{Var}($ FTSEMIB)

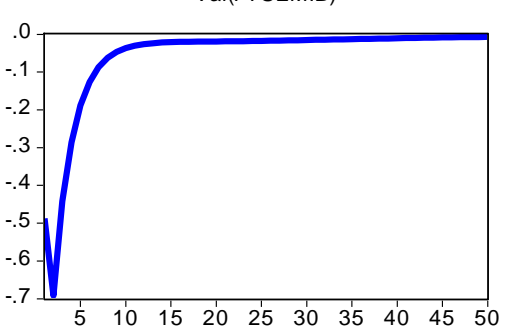

$\operatorname{Var}(\mathrm{CAC} 40)$

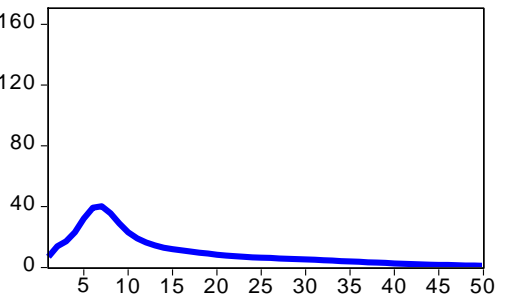

$\operatorname{Var}($ WIG20)

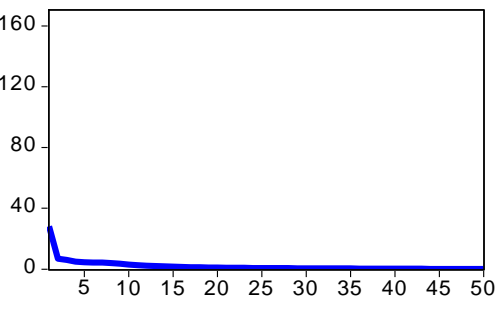

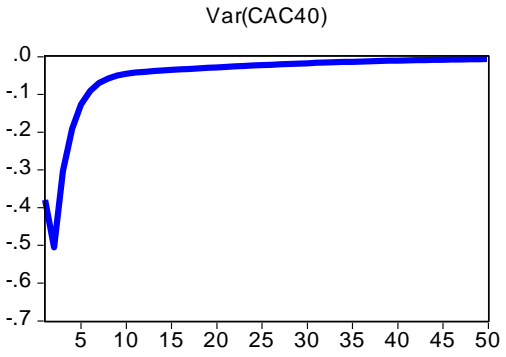

Var(WIG20)

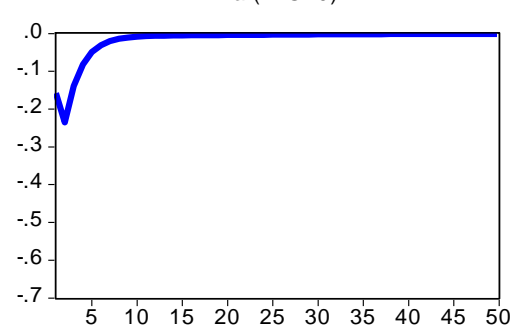

Note: $Y$ axes measure percentage changes to variances, while $X$ axes represent days. 
Figure 4 Covariance impulse response functions of Brexit-related events

A: The announcement of the EU referendum date on $21^{\text {st }}$ February 2016
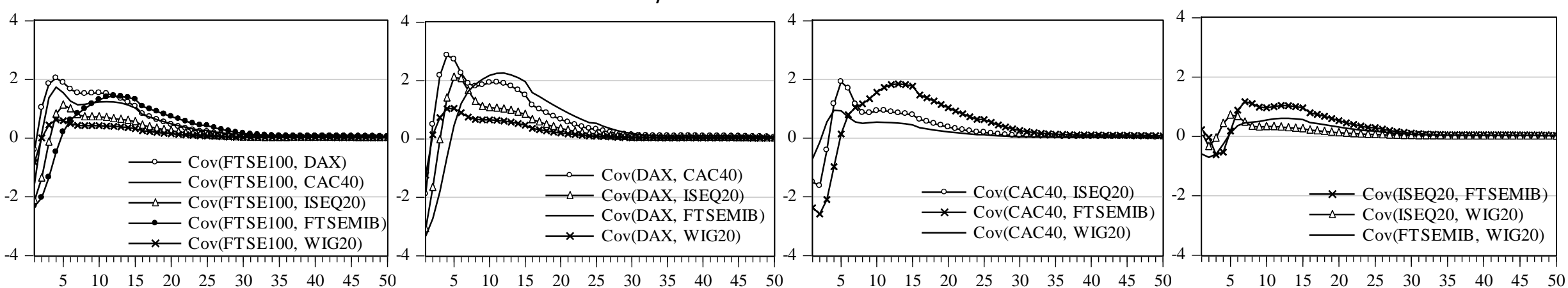

B: The return of the EU referendum result on $24^{\text {th }}$ June 2016
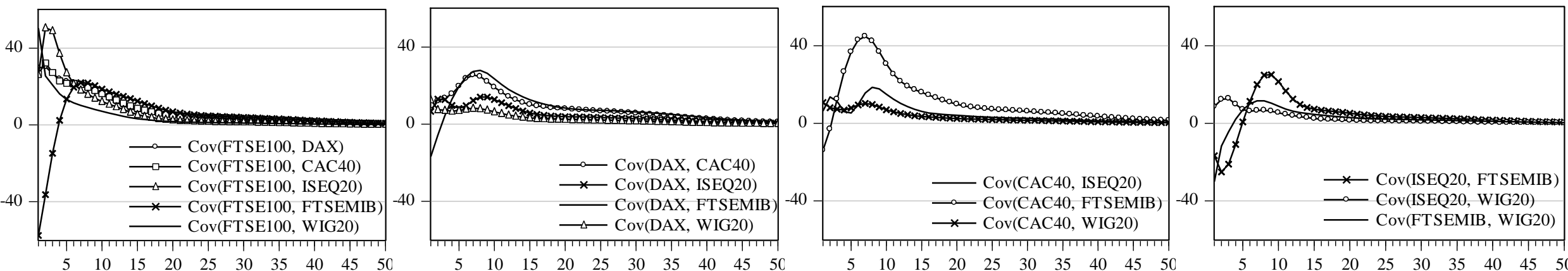

C: The invocation of Article 50 of the Treaty on European Union on 29 ${ }^{\text {th }}$ March 2017
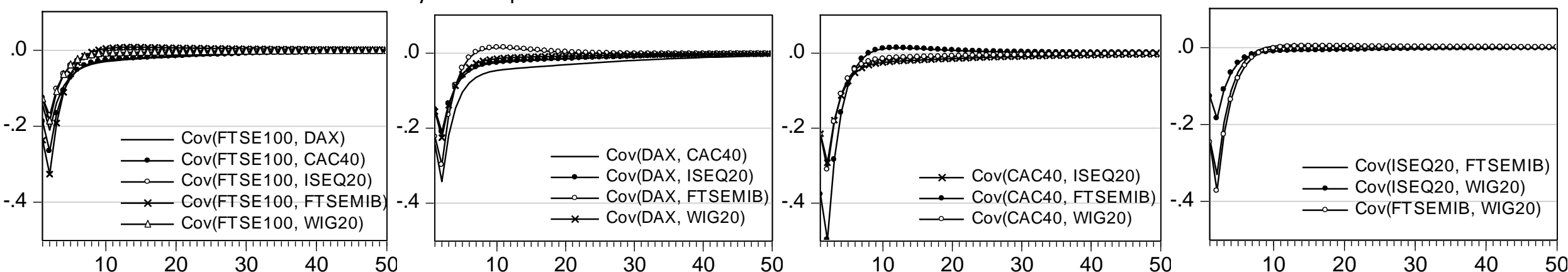

Note: $Y$ axes measure percentage changes to variances, while $X$ axes represent days. 
Table 1 Summary statistics of the intra-day market returns

\begin{tabular}{|c|c|c|c|c|c|c|}
\hline & DAX & CAC40 & ISEQ20 & \multirow[t]{2}{*}{ FTSEMIB } & WIG20 \\
\hline & & \multicolumn{4}{|c|}{ 04/01/2016-21/10/2017 } & \\
\hline Mean & 0.002 & 0.002 & 0.002 & 0.000 & -0.002 & 0.002 \\
\hline Std. Dev. & 0.155 & 0.194 & 0.195 & 0.170 & 0.276 & 0.196 \\
\hline Skewness & 0.370 & -0.227 & 0.198 & 0.077 & -0.966 & -0.027 \\
\hline Kurtosis & 14.62 & 11.45 & 13.04 & 12.03 & 39.66 & 6.01 \\
\hline Jarque-Bera & $40267 * * *$ & $21288 * * *$ & $29994 * * *$ & $24217 * * *$ & $400442 * * *$ & $2688^{* * *}$ \\
\hline Observations & 7132 & 7132 & 7132 & 7132 & 7132 & 7132 \\
\hline \multicolumn{7}{|c|}{$24 / 06 / 2015-23 / 06 / 2016$} \\
\hline Mean & -0.001 & -0.007 & -0.005 & -0.004 & -0.009 & -0.006 \\
\hline Std. Dev. & 0.241 & 0.279 & 0.274 & 0.200 & 0.321 & 0.226 \\
\hline Skewness & 0.107 & -0.301 & -0.037 & 0.056 & 0.210 & -0.047 \\
\hline Kurtosis & 17.14 & 7.338 & 9.772 & 10.79 & 11.79 & 6.670 \\
\hline Jarque-Bera & $33384 * * *$ & $3199.2^{* * *}$ & $7652 * * *$ & $10128 * * *$ & $12917 * * *$ & $2248 * * *$ \\
\hline Observations & 4004 & 4004 & 4004 & 4004 & 4004 & 4004 \\
\hline \multicolumn{7}{|c|}{ 24/06/2016-23/06/2017 } \\
\hline Mean & 0.003 & 0.005 & 0.004 & 0.003 & 0.001 & 0.004 \\
\hline Std. Dev. & 0.140 & 0.161 & 0.169 & 0.163 & 0.251 & 0.195 \\
\hline Skewness & 1.169 & 0.169 & 0.395 & 0.276 & -2.715 & -0.067 \\
\hline Kurtosis & 25.10 & 9.571 & 11.37 & 13.65 & 78.67 & 6.675 \\
\hline Jarque-Bera & $81299 * * *$ & $7124 * * *$ & $11624^{* * *}$ & $18702 * * *$ & $947311^{* * *}$ & $2225 * * *$ \\
\hline Observations & 3950 & 3950 & 3950 & 3950 & 3950 & 3950 \\
\hline
\end{tabular}

Note: $* * *$ represents $1 \%$ level of significance. 
Table 2 Tests for adequacy and specification of VAR(4)-6x6 BEKK-GARCH $(1,1)$

\section{4/01/2016- 21/10/2017}

A: Diagnostic statistics for model adequacy

\begin{tabular}{|c|c|c|c|c|c|c|}
\hline & FTSE100 & DAX & CAC40 & ISEQ20 & FTSEMIB & WIG20 \\
\hline Ljung-Box Q(6) & $12.47 *$ & $19.92 * * *$ & 9.98 & $10.97 *$ & 5.64 & 9.60 \\
\hline Ljung-Box Q(12) & $23.22 * *$ & $23.37 * *$ & 15.13 & 18.94 & 10.05 & 16.86 \\
\hline Multivariate $\mathrm{Q}(6)$ & \multicolumn{6}{|l|}{222.39} \\
\hline Multivariate $\mathrm{Q}(12)$ & \multicolumn{6}{|l|}{459.43} \\
\hline \multicolumn{7}{|c|}{ Eigenvalue $\mathrm{A} \otimes \mathrm{A}+\mathrm{B} \otimes \mathrm{B}$} \\
\hline FTSE100 & $(0.998,0.000)$ & & & & & \\
\hline DAX & $(0.996,-0.001)$ & $(0.996,0.001)$ & & & & \\
\hline CAC40 & $(0.992,-0.005)$ & $(0.992,0.005)$ & $(0.992,-0.004)$ & & & \\
\hline ISEQ20 & $(0.992,0.004)$ & $(0.991,-0.000)$ & $(0.991,0.000)$ & $(0.988,-0.000)$ & & \\
\hline FTSEMIB & $(0.988,0.009)$ & $(0.988,-0.009)$ & $(0.988,0.000)$ & $(0.987,-0.004)$ & $(0.987,0.004)$ & \\
\hline WIG20 & $(0.715,0.000)$ & $(0.709,-0.000)$ & $(0.706,-0.000)$ & $(0.702,-0.003)$ & $(0.702,0.003)$ & $(0.537,0.000)$ \\
\hline \multicolumn{7}{|c|}{ B: Likelihood ratio test statistics for model specification } \\
\hline \multicolumn{2}{|c|}{ Mean equations have constants only. } & \multicolumn{4}{|c|}{ H0: $\Phi_{\mathrm{p}}=0 \quad(\mathrm{p}=1,2, \ldots, 4 ;$ d.f. $=144)$} & $\chi^{2}=726.81 * * *$ \\
\hline \multicolumn{2}{|c|}{ Multivariate v univariate GARCH } & \multicolumn{4}{|c|}{ H0: $\varphi_{p i j}=a_{i j} a_{j i}=b_{i j} b_{j i}=0 \quad(p=1,2, \ldots, 4 ; i \neq j ; d . f .=180)$} & $\chi^{2}=1240.5 * * *$ \\
\hline \multicolumn{2}{|c|}{ Fully-fledged v diagonal BEKK } & \multicolumn{4}{|c|}{ H0: $a_{i j}=b_{i j}=0 \quad(i \neq j ;$ d.f. $=60)$} & $\chi^{2}=468.89 * * *$ \\
\hline
\end{tabular}

\section{4/06/2015 - 23/06/2016}

A: Diagnostic statistics for model adequacy

\begin{tabular}{|c|c|c|c|c|c|c|}
\hline & FTSE100 & DAX & CAC40 & ISEQ20 & FTSEMIB & WIG20 \\
\hline Ljung-Box Q(6) & $20.96 * * *$ & 7.58 & 8.11 & 5.22 & 9.93 & 5.77 \\
\hline Ljung-Box Q(12) & $31.00 * * *$ & 13.39 & 12.25 & 12.27 & 16.47 & 12.16 \\
\hline Multivariate $\mathrm{Q}(6)$ & \multicolumn{6}{|l|}{211.69} \\
\hline Multivariate Q(12) & \multicolumn{6}{|l|}{439.72} \\
\hline \multicolumn{7}{|c|}{ Eigenvalue $\mathrm{A} \otimes \mathrm{A}+\mathrm{B} \otimes \mathrm{B}$} \\
\hline FTSE100 & $(0.997,0.000)$ & & & & & \\
\hline DAX & $(0.995,-0.000)$ & $(0.995,0.000)$ & & & & \\
\hline CAC40 & $(0.994,0.000)$ & $(0.993,-0.000)$ & $(0.991,0.000)$ & & & \\
\hline ISEQ20 & $(0.947,-0.000)$ & $(0.945,0.000)$ & $(0.938,-0.000)$ & $(0.912,-0.002)$ & & \\
\hline FTSEMIB & $(0.912,0.002)$ & $(0.910,-0.000)$ & $(0.904,0.000)$ & $(0.858,0.000)$ & $(0.835,-0.000)$ & \\
\hline WIG20 & $(0.638,0.000)$ & $(0.634,0.000)$ & $(0.623,0.000)$ & $(0.609,0.000)$ & $(0.582,0.000)$ & $(0.463,-0.000)$ \\
\hline \multicolumn{7}{|c|}{ B: Likelihood ratio test statistics for model specification } \\
\hline \multicolumn{2}{|c|}{ Mean equations have constants only. } & \multicolumn{4}{|c|}{ H0: $\Phi_{\mathrm{p}}=0 \quad(\mathrm{p}=1,2, \ldots, 4 ;$ d.f. $=144)$} & $\chi^{2}=1297.1 * * *$ \\
\hline \multicolumn{2}{|c|}{ Multivariate v univariate GARCH } & \multicolumn{4}{|c|}{ H0: $\varphi_{p i j}=a_{i j} a_{j i}=b_{i j} b_{j i}=0 \quad(p=1,2, \ldots, 4 ; i \neq j ; d . f .=180)$} & $\chi^{2}=2558 * * *$ \\
\hline \multicolumn{2}{|c|}{ Fully-fledged v diagonal BEKK } & \multicolumn{4}{|c|}{ H0: $a_{i j}=b_{i j}=0 \quad(i \neq j ;$ d.f. $=60)$} & $\chi^{2}=362.73 * * *$ \\
\hline
\end{tabular}

24/06/2016 - 23/06/2017

A: Diagnostic statistics for model adequacy

\begin{tabular}{|c|c|c|c|c|c|c|}
\hline & FTSE100 & DAX & CAC40 & ISEQ20 & FTSEMIB & WIG20 \\
\hline Ljung-Box Q(6) & 4.304 & $16.11 * *$ & 5.753 & $11.33^{*}$ & 5.26 & 9.19 \\
\hline Ljung-Box Q(12) & 13.17 & $23.35 * *$ & 7.99 & $22.34 * *$ & 10.45 & 15.52 \\
\hline Multivariate Q(6) & \multicolumn{6}{|l|}{176.54} \\
\hline Multivariate Q(12) & \multicolumn{6}{|l|}{365.45} \\
\hline \multicolumn{7}{|c|}{ Eigenvalue $\mathrm{A} \otimes \mathrm{A}+\mathrm{B} \otimes \mathrm{B}$} \\
\hline FTSE100 & $(0.994,0.000)$ & & & & & \\
\hline DAX & $(0.993,-0.001)$ & $(0.992,-0.004)$ & & & & \\
\hline CAC40 & $(0.992,0.004)$ & $(0.992,-0.008)$ & $(0.992,0.008)$ & & & \\
\hline ISEQ20 & $(0.985,0.000)$ & $(0.985,-0.004)$ & $(0.985,0.004)$ & $(0.980,-0.000)$ & & \\
\hline FTSEMIB & $(0.947,-0.000)$ & $(0.941,-0.006)$ & $(0.941,0.006)$ & $(0.935,-0.000)$ & $(0.908,-0.000)$ & \\
\hline WIG20 & $(0.881,0.004)$ & $(0.881,-0.004)$ & $(0.880,-0.000)$ & $(0.875,-0.000)$ & $(0.838,0.000)$ & $(0.784,0.000)$ \\
\hline \multicolumn{7}{|c|}{ B: Likelihood ratio test statistics for model specification } \\
\hline \multicolumn{2}{|c|}{ Mean equations have constants only. } & \multicolumn{4}{|c|}{$\Phi_{\mathrm{p}}=0 \quad(\mathrm{p}=1,2, \ldots, 4 ;$ d.f. $=144)$} & $\chi^{2}=255.06 * * *$ \\
\hline \multicolumn{2}{|c|}{ Multivariate v univariate GARCH } & \multicolumn{4}{|c|}{$\varphi_{p i j}=a_{i j} a_{j i}=b_{i j} b_{j i}=0 \quad(p=1,2, \ldots, 4 ; i \neq j ;$ d.f. $=180)$} & $\chi^{2}=616.99 * * *$ \\
\hline \multicolumn{2}{|c|}{ Fully-fledged v diagonal BEKK } & \multicolumn{4}{|c|}{$a_{i j}=b_{i j}=0 \quad(i \neq j ;$ d.f. $=60)$} & $\chi^{2}=296.79 * * *$ \\
\hline
\end{tabular}


Table 3 Likelihood ratio tests for return and volatility spillovers estimated by VAR(4)-6x6 BEKKGARCH(1, 1), 04/01/2016 - 21/10/2017

\begin{tabular}{|c|c|c|c|c|c|}
\hline & $\mathrm{HO}$ & $\chi^{2}$ statistic & & H0 & $\chi^{2}$ statistic \\
\hline \multirow[t]{6}{*}{$\begin{array}{l}\text { From FTSE100 } \\
\text { to other(s) }\end{array}$} & $\begin{array}{l}\varphi_{\mathrm{pi} 1}=\mathrm{a}_{\mathrm{i} 1}=\mathrm{g}_{\mathrm{i} 1}=0 \\
(\mathrm{p}=1,2, \ldots, 4 ; \mathrm{i} \neq 1 ; \text { d.f. }=30)\end{array}$ & $76.35 * * *$ & \multirow[t]{6}{*}{$\begin{array}{l}\text { From other(s) } \\
\text { to FTSE100 }\end{array}$} & $\begin{array}{l}\varphi_{\mathrm{plj}}=\mathrm{a}_{1 \mathrm{j}}=\mathrm{g}_{1 \mathrm{j}}=0 \\
(\mathrm{p}=1,2 \ldots, 4 ; \mathrm{j} \neq 1 ; \text { d.f. }=30)\end{array}$ & $103.87 * * *$ \\
\hline & $\begin{array}{l}\varphi_{\mathrm{p} 21}=\mathrm{a}_{21}=\mathrm{g}_{21}=0 \\
(\mathrm{p}=1,2, \ldots, 4 ; \text { d.f. }=6)\end{array}$ & $29.16^{* * * *}$ & & $\begin{array}{l}\varphi_{\mathrm{plj}}=\mathrm{a}_{12}=\mathrm{g}_{12}=0 \\
(\mathrm{p}=1,2 \ldots, 4 ; \text { d.f. }=6)\end{array}$ & 10.06 \\
\hline & $\begin{array}{l}\varphi_{\mathrm{p} 31}=\mathrm{a}_{31}=\mathrm{g}_{31}=0 \\
(\mathrm{p}=1,2, \ldots, 4 ; \text { d.f. }=6)\end{array}$ & $10.73^{*}$ & & $\begin{array}{l}\varphi_{\mathrm{p} 13}=\mathrm{a}_{13}=\mathrm{g}_{13}=0 \\
(\mathrm{p}=1,2 \ldots, 4 ; \text { d.f. }=6)\end{array}$ & $36.90 * * *$ \\
\hline & $\begin{array}{l}\varphi_{\mathrm{p} 41}=a_{41}=g_{41}=0 \\
(p=1,2, \ldots, 4 ; \text { d.f. }=6)\end{array}$ & 7.20 & & $\begin{array}{l}\varphi_{\mathrm{p} 14}=\mathrm{a}_{14}=\mathrm{g}_{14}=0 \\
(\mathrm{p}=1,2 \ldots, 4 ; \text { d.f. }=6)\end{array}$ & $11.51 *$ \\
\hline & $\begin{array}{l}\varphi_{\mathrm{p} 51}=\mathrm{a}_{51}=\mathrm{g}_{51}=0 \\
(\mathrm{p}=1,2, \ldots, 4 ; \text { d.f. }=6)\end{array}$ & 6.63 & & $\begin{array}{l}\varphi_{\mathrm{p} 15}=\mathrm{a}_{15}=\mathrm{g}_{15}=0 \\
(\mathrm{p}=1,2 \ldots, 4 ; \text { d.f. }=6)\end{array}$ & $21.95 * * *$ \\
\hline & $\begin{array}{l}\varphi_{\mathrm{p} 61}=\mathrm{a}_{61}=\mathrm{g}_{61}=0 \\
(\mathrm{p}=1,2, \ldots, 4 ; \text { d.f. }=6)\end{array}$ & $12.01 *$ & & $\begin{array}{l}\varphi_{\mathrm{p} 16}=\mathrm{a}_{16}=\mathrm{g}_{16}=0 \\
(\mathrm{p}=1,2 \ldots, 4 ; \text { d.f. }=6)\end{array}$ & 9.58 \\
\hline \multirow[t]{5}{*}{$\begin{array}{l}\text { From DAX to } \\
\text { other(s) }\end{array}$} & $\begin{array}{l}\varphi_{\mathrm{pi} 2}=\mathrm{a}_{\mathrm{i} 2}=\mathrm{g}_{\mathrm{i} 2}=0 \\
(\mathrm{p}=1,2, \ldots, 4 ; \mathrm{i} \neq 2 ; \text { d.f. }=30)\end{array}$ & $123.81 * * *$ & \multirow[t]{5}{*}{$\begin{array}{l}\text { From other(s) } \\
\text { to DAX }\end{array}$} & $\begin{array}{l}\varphi_{\mathrm{p} 2 \mathrm{j}}=\mathrm{a}_{2 \mathrm{j}}=\mathrm{g}_{2 \mathrm{j}}=0 \\
(\mathrm{p}=1,2 \ldots, 4 ; \mathrm{j} \neq 2 ; \text { d.f. }=30)\end{array}$ & $146.80 * * *$ \\
\hline & $\begin{array}{l}\varphi_{\mathrm{p} 32}=\mathrm{a}_{32}=\mathrm{g}_{32}=0 \\
(\mathrm{p}=1,2, \ldots, 4 ; \text { d.f. }=6)\end{array}$ & $26.36 * * *$ & & $\begin{array}{l}\varphi_{\mathrm{p} 23}=\mathrm{a}_{23}=\mathrm{g}_{23}=0 \\
(\mathrm{p}=1,2 \ldots, 4 ; \text { d.f. }=6)\end{array}$ & $59.01 * * *$ \\
\hline & $\begin{array}{l}\varphi_{\mathrm{p} 42}=\mathrm{a}_{42}=\mathrm{g}_{42}=0 \\
(\mathrm{p}=1,2, \ldots, 4 ; \text { d.f. }=6)\end{array}$ & $13.29 * *$ & & $\begin{array}{l}\varphi_{\mathrm{p} 24}=\mathrm{a}_{24}=\mathrm{g}_{24}=0 \\
(\mathrm{p}=1,2 \ldots, 4 ; \text { d.f. }=6)\end{array}$ & 9.47 \\
\hline & $\begin{array}{l}\varphi_{\mathrm{p} 52}=\mathrm{a}_{52}=\mathrm{g}_{52}=0 \\
(\mathrm{p}=1,2, \ldots, 4 ; \text { d.f. }=6)\end{array}$ & 5.25 & & $\begin{array}{l}\varphi_{\mathrm{p} 25}=\mathrm{a}_{25}=\mathrm{g}_{25}=0 \\
(\mathrm{p}=1,2 \ldots, 4 ; \text { d.f. }=6)\end{array}$ & $36.40 * * *$ \\
\hline & $\begin{array}{l}\varphi_{\mathrm{p} 62}=\mathrm{a}_{62}=\mathrm{g}_{62}=0 \\
(\mathrm{p}=1,2, \ldots, 4 ; \text { d.f. }=6)\end{array}$ & $44.68 * * *$ & & $\begin{array}{l}\varphi_{\mathrm{p} 26}=\mathrm{a}_{26}=\mathrm{g}_{26}=0 \\
(\mathrm{p}=1,2 \ldots, 4 ; \text { d.f. }=6)\end{array}$ & $18.69 * * *$ \\
\hline \multirow[t]{4}{*}{$\begin{array}{l}\text { From CAC40 to } \\
\text { other(s) }\end{array}$} & $\begin{array}{l}\varphi_{\mathrm{pi} 3}=\mathrm{a}_{\mathrm{i} 3}=\mathrm{g}_{\mathrm{i} 3}=0 \\
(\mathrm{p}=1,2, \ldots, 4 ; \mathrm{i} \neq 3 ; \text { d.f. }=30)\end{array}$ & $271851 * * *$ & \multirow[t]{4}{*}{$\begin{array}{l}\text { From other(s) } \\
\text { to CAC40 }\end{array}$} & $\begin{array}{l}\varphi_{\mathrm{p} 3 \mathrm{j}}=\mathrm{a}_{3 \mathrm{j}}=\mathrm{g}_{3 \mathrm{j}}=0 \\
(\mathrm{p}=1,2 \ldots, 4 ; \mathrm{j} \neq 3 ; \text { d.f. }=30)\end{array}$ & $106.74 * * *$ \\
\hline & $\begin{array}{l}\varphi_{\mathrm{p} 43}=\mathrm{a}_{43}=\mathrm{g}_{43}=0 \\
(\mathrm{p}=1,2, \ldots, 4 ; \text { d.f. }=6)\end{array}$ & $29.24 * * *$ & & $\begin{array}{l}\varphi_{\mathrm{p} 34}=\mathrm{a}_{34}=\mathrm{g}_{34}=0 \\
(\mathrm{p}=1,2 \ldots, 4 ; \text { d.f. }=6)\end{array}$ & 5.76 \\
\hline & $\begin{array}{l}\varphi_{\mathrm{p} 53}=\mathrm{a}_{53}=\mathrm{g}_{53}=0 \\
(\mathrm{p}=1,2, \ldots, 4 ; \text { d.f. }=6)\end{array}$ & $16.63 * *$ & & $\begin{array}{l}\varphi_{\mathrm{p} 35}=\mathrm{a}_{35}=\mathrm{g}_{35}=0 \\
(\mathrm{p}=1,2 \ldots, 4 ; \text { d.f. }=6)\end{array}$ & $30.97 * * *$ \\
\hline & $\begin{array}{l}\varphi_{\mathrm{p} 63}=\mathrm{a}_{63}=\mathrm{g}_{63}=0 \\
(\mathrm{p}=1,2, \ldots, 4 ; \text { d.f. }=6)\end{array}$ & $21.64 * * *$ & & $\begin{array}{l}\varphi_{\mathrm{p} 36}=\mathrm{a}_{36}=\mathrm{g}_{36}=0 \\
(\mathrm{p}=1,2 \ldots, 4 ; \text { d.f. }=6)\end{array}$ & $13.83^{*}$ \\
\hline \multirow[t]{3}{*}{$\begin{array}{l}\text { From ISEQ20 to } \\
\text { other(s) }\end{array}$} & $\begin{array}{l}\varphi_{\mathrm{pi} 4}=\mathrm{a}_{\mathrm{i} 4}=\mathrm{g}_{\mathrm{i} 4}=0 \\
(\mathrm{p}=1,2, \ldots, 4 ; \mathrm{i} \neq 4 ; \text { d.f. }=30)\end{array}$ & $60.09 * * *$ & \multirow[t]{3}{*}{$\begin{array}{l}\text { From other(s) } \\
\text { to ISEQ20 }\end{array}$} & $\begin{array}{l}\varphi_{\mathrm{p} 4 \mathrm{j}}=\mathrm{a}_{4 \mathrm{j}}=\mathrm{g}_{4 \mathrm{j}}=0 \\
(\mathrm{p}=1,2 \ldots, 4 ; \mathrm{j} \neq 4 ; \text { d.f. }=30)\end{array}$ & $101.38 * * *$ \\
\hline & $\begin{array}{l}\varphi_{\mathrm{p} 54}=\mathrm{a}_{54}=\mathrm{g}_{54}=0 \\
(\mathrm{p}=1,2, \ldots, 4 ; \text { d.f. }=6)\end{array}$ & 7.84 & & $\begin{array}{l}\varphi_{\mathrm{p} 45}=\mathrm{a}_{45}=\mathrm{g}_{45}=0 \\
(\mathrm{p}=1,2 \ldots, 4 ; \text { d.f. }=6)\end{array}$ & $16.17 * *$ \\
\hline & $\begin{array}{l}\varphi_{\mathrm{p} 64}=\mathrm{a}_{64}=\mathrm{g}_{64}=0 \\
(\mathrm{p}=1,2, \ldots, 4 ; \text { d.f. }=6)\end{array}$ & 9.59 & & $\begin{array}{l}\varphi_{\mathrm{p} 46}=\mathrm{a}_{46}=\mathrm{g}_{46}=0 \\
(\mathrm{p}=1,2 \ldots, 4 ; \text { d.f. }=6)\end{array}$ & $12.69 * *$ \\
\hline \multirow[t]{2}{*}{$\begin{array}{l}\text { From FTSEMIB } \\
\text { to other(s) }\end{array}$} & $\begin{array}{l}\varphi_{\mathrm{pi} 5}=\mathrm{a}_{\mathrm{i} 5}=\mathrm{g}_{\mathrm{i} 5}=0 \\
(\mathrm{p}=1,2, \ldots, 4 ; \mathrm{i} \neq 5 ; \text { d.f. }=30)\end{array}$ & $130.83 * * *$ & \multirow[t]{2}{*}{$\begin{array}{l}\text { From other(s) } \\
\text { to FTSEMIB }\end{array}$} & $\begin{array}{l}\varphi_{\mathrm{p} 5 \mathrm{j}}=\mathrm{a}_{5 \mathrm{j}}=\mathrm{g}_{5 \mathrm{j}}=0 \\
(\mathrm{p}=1,2 \ldots, 4 ; \mathrm{j} \neq 5 ; \text { d.f. }=30)\end{array}$ & $49.28 * *$ \\
\hline & $\begin{array}{l}\varphi_{\mathrm{p} 54}=\mathrm{a}_{54}=\mathrm{g}_{54}=0 \\
(\mathrm{p}=1,2, \ldots, 4 ; \text { d.f. }=6)\end{array}$ & $35.71 * * *$ & & $\begin{array}{l}\varphi_{\mathrm{p} 45}=\mathrm{a}_{45}=\mathrm{g}_{45}=0 \\
(\mathrm{p}=1,2 \ldots, 4 ; \text { d.f. }=6)\end{array}$ & $12.07 *$ \\
\hline $\begin{array}{l}\text { From WIG20 to } \\
\text { others }\end{array}$ & $\begin{array}{l}\varphi_{\mathrm{pi} 6}=\mathrm{a}_{\mathrm{i} 6}=\mathrm{g}_{\mathrm{i} 6}=0 \\
(\mathrm{p}=1,2, \ldots, 4 ; \mathrm{i} \neq 6 ; \text { d.f. }=30)\end{array}$ & $51.68 * * *$ & $\begin{array}{l}\text { From others to } \\
\text { WIG20 }\end{array}$ & $\begin{array}{l}\varphi_{p 6 j}=a_{6 j}=g_{6 j}=0 \\
(p=1,2 \ldots, 4 ; j \neq 6 ; \text { d.f. }=30)\end{array}$ & $113.39 * * *$ \\
\hline
\end{tabular}

Note: FTSE100, DAX, CAC40, ISEQ20, FTSEMIB and WIG20 are, respectively, indexed as 1, 2, 3, 4, 5 and 6. 
Table 4 Likelihood ratio tests for return and volatility spillovers estimated by VAR(4)-6x6 BEKK$\operatorname{GARCH}(1,1)$, sub-periods

\begin{tabular}{|c|c|c|c|c|c|}
\hline & $\mathrm{HO}$ & $\chi^{2}$ statistic & & $\mathrm{HO}$ & $\chi^{2}$ statistic \\
\hline \multicolumn{6}{|c|}{$24 / 06 / 2015-23 / 06 / 2016$} \\
\hline \multirow[t]{6}{*}{$\begin{array}{l}\text { From FTSE100 } \\
\text { to other(s) }\end{array}$} & $\begin{array}{l}\varphi_{\mathrm{pi} 1}=\mathrm{a}_{\mathrm{i} 1}=\mathrm{g}_{\mathrm{i} 1}=0 \\
(\mathrm{p}=1,2, \ldots, 4 ; \mathrm{i} \neq 1 ; \text { d.f. }=30)\end{array}$ & $713.02 * * *$ & \multirow[t]{6}{*}{$\begin{array}{l}\text { From other(s) } \\
\text { to FTSE100 }\end{array}$} & $\begin{array}{l}\varphi_{\mathrm{p} 1 \mathrm{j}}=\mathrm{a}_{1 \mathrm{j}}=\mathrm{g}_{1 \mathrm{j}}=0 \\
(\mathrm{p}=1,2 \ldots, 4 ; \mathrm{j} \neq 1 ; \text { d.f. }=30)\end{array}$ & $60.82 * * *$ \\
\hline & $\begin{array}{l}\varphi_{\mathrm{p} 21}=\mathrm{a}_{21}=\mathrm{g}_{21}=0 \\
(\mathrm{p}=1,2, \ldots, 4 ; \text { d.f. }=6)\end{array}$ & $481.54 * * *$ & & $\begin{array}{l}\varphi_{\mathrm{p} 1 \mathrm{j}}=\mathrm{a}_{12}=\mathrm{g}_{12}=0 \\
(\mathrm{p}=1,2 \ldots, 4 ; \text { d.f. }=6)\end{array}$ & $11.25^{*}$ \\
\hline & $\begin{array}{l}\varphi_{\mathrm{p} 31}=\mathrm{a}_{31}=\mathrm{g}_{31}=0 \\
(\mathrm{p}=1,2, \ldots, 4 ; \text { d.f. }=6)\end{array}$ & $636.94 * * *$ & & $\begin{array}{l}\varphi_{\mathrm{p} 13}=\mathrm{a}_{13}=\mathrm{g}_{13}=0 \\
(\mathrm{p}=1,2 \ldots, 4 ; \text { d.f. }=6)\end{array}$ & 10.62 \\
\hline & $\begin{array}{l}\varphi_{\mathrm{p} 41}=\mathrm{a}_{41}=\mathrm{g}_{41}=0 \\
(\mathrm{p}=1,2, \ldots, 4 ; \text { d.f. }=6)\end{array}$ & $287.30 * * *$ & & $\begin{array}{l}\varphi_{\mathrm{p} 14}=\mathrm{a}_{14}=\mathrm{g}_{14}=0 \\
(\mathrm{p}=1,2 \ldots, 4 ; \text { d.f. }=6)\end{array}$ & 4.67 \\
\hline & $\begin{array}{l}\varphi_{\mathrm{p} 51}=\mathrm{a}_{51}=\mathrm{g}_{51}=0 \\
(\mathrm{p}=1,2, \ldots, 4 ; \text { d.f. }=6)\end{array}$ & $401.10 * * *$ & & $\begin{array}{l}\varphi_{p 15}=a_{15}=g_{15}=0 \\
(p=1,2 \ldots, 4 ; \text { d.f. }=6)\end{array}$ & $27.86 * * *$ \\
\hline & $\begin{array}{l}\varphi_{\mathrm{p} 61}=\mathrm{a}_{61}=\mathrm{g}_{61}=0 \\
(\mathrm{p}=1,2, \ldots, 4 ; \text { d.f. }=6)\end{array}$ & $100.83 * * *$ & & $\begin{array}{l}\varphi_{\mathrm{p} 16}=\mathrm{a}_{16}=\mathrm{g}_{16}=0 \\
(\mathrm{p}=1,2 \ldots, 4 ; \text { d.f. }=6)\end{array}$ & 8.35 \\
\hline $\begin{array}{l}\text { From DAX to } \\
\text { other(s) }\end{array}$ & $\begin{array}{l}\varphi_{\mathrm{pi} 2}=\mathrm{a}_{\mathrm{i} 2}=\mathrm{g}_{\mathrm{i} 2}=0 \\
(\mathrm{p}=1,2, \ldots, 4 ; \mathrm{i} \neq 2 ; \text { d.f. }=30)\end{array}$ & $49.13 * * *$ & $\begin{array}{l}\text { From other(s) } \\
\text { to DAX }\end{array}$ & $\begin{array}{l}\varphi_{\mathrm{p} 2 \mathrm{j}}=\mathrm{a}_{2 \mathrm{j}}=\mathrm{g}_{2 \mathrm{j}}=0 \\
(\mathrm{p}=1,2 \ldots, 4 ; \mathrm{j} \neq 2 ; \text { d.f. }=30)\end{array}$ & $572.66 * * *$ \\
\hline $\begin{array}{l}\text { From CAC40 to } \\
\text { other(s) }\end{array}$ & $\begin{array}{l}\varphi_{\mathrm{pi} 3}=\mathrm{a}_{\mathrm{i} 3}=\mathrm{g}_{\mathrm{i} 3}=0 \\
(\mathrm{p}=1,2, \ldots, 4 ; \mathrm{i} \neq 3 ; \text { d.f. }=30)\end{array}$ & 4.87 & $\begin{array}{l}\text { From other(s) } \\
\text { to CAC40 }\end{array}$ & $\begin{array}{l}\varphi_{\mathrm{p} 3 \mathrm{j}}=\mathrm{a}_{3 \mathrm{j}}=\mathrm{g}_{3 \mathrm{j}}=0 \\
(\mathrm{p}=1,2 \ldots, 4 ; \mathrm{j} \neq 3 ; \text { d.f. }=30)\end{array}$ & $35.15^{* * *}$ \\
\hline $\begin{array}{l}\text { From ISEQ20 to } \\
\text { other(s) }\end{array}$ & $\begin{array}{l}\varphi_{\mathrm{pi} 4}=\mathrm{a}_{\mathrm{i} 4}=\mathrm{g}_{\mathrm{i} 4}=0 \\
(\mathrm{p}=1,2, \ldots, 4 ; \mathrm{i} \neq 4 ; \text { d.f. }=30)\end{array}$ & 6.83 & $\begin{array}{l}\text { From other(s) } \\
\text { to ISEQ20 }\end{array}$ & $\begin{array}{l}\varphi_{\mathrm{p} 4 \mathrm{j}}=\mathrm{a}_{4 \mathrm{j}}=\mathrm{g}_{4 \mathrm{j}}=0 \\
(\mathrm{p}=1,2 \ldots, 4 ; \mathrm{j} \neq 4 ; \text { d.f. }=30)\end{array}$ & 4.90 \\
\hline $\begin{array}{l}\text { From FTSEMIB } \\
\text { to other }(\mathrm{s})\end{array}$ & $\begin{array}{l}\varphi_{\mathrm{pi} 5}=\mathrm{a}_{\mathrm{i} 5}=\mathrm{g}_{\mathrm{i} 5}=0 \\
(\mathrm{p}=1,2, \ldots, 4 ; \mathrm{i} \neq 5 ; \text { d.f. }=30)\end{array}$ & $16.88 * * *$ & $\begin{array}{l}\text { From other(s) } \\
\text { to FTSEMIB }\end{array}$ & $\begin{array}{l}\varphi_{\mathrm{p} 5 \mathrm{j}}=\mathrm{a}_{5 \mathrm{j}}=\mathrm{g}_{5 \mathrm{j}}=0 \\
(\mathrm{p}=1,2 \ldots, 4 ; \mathrm{j} \neq 5 ; \text { d.f. }=30)\end{array}$ & $44.07 * * *$ \\
\hline $\begin{array}{l}\text { From WIG20 to } \\
\text { others }\end{array}$ & $\begin{array}{l}\varphi_{\mathrm{pi}}=\mathrm{a}_{\mathrm{i} 6}=\mathrm{g}_{\mathrm{i} 6}=0 \\
(\mathrm{p}=1,2, \ldots, 4 ; \mathrm{i} \neq 6 ; \text { d.f. }=30)\end{array}$ & 5.37 & $\begin{array}{l}\text { From others to } \\
\text { WIG20 }\end{array}$ & $\begin{array}{l}\varphi_{\mathrm{p} 6 \mathrm{j}}=\mathrm{a}_{6 \mathrm{j}}=\mathrm{g}_{6 \mathrm{j}}=0 \\
(\mathrm{p}=1,2 \ldots, 4 ; \mathrm{j} \neq 6 ; \text { d.f. }=30)\end{array}$ & $14.49 * *$ \\
\hline \multicolumn{6}{|c|}{$24 / 06 / 2016-23 / 06 / 2017$} \\
\hline \multirow[t]{6}{*}{$\begin{array}{l}\text { From FTSE100 } \\
\text { to other(s) }\end{array}$} & $\begin{array}{l}\varphi_{\mathrm{pi} 1}=\mathrm{a}_{\mathrm{i} 1}=\mathrm{g}_{\mathrm{i} 1}=0 \\
(\mathrm{p}=1,2, \ldots, 4 ; \mathrm{i} \neq 1 ; \text { d.f. }=30)\end{array}$ & $68.25 * * *$ & \multirow[t]{6}{*}{$\begin{array}{l}\text { From other(s) } \\
\text { to FTSE100 }\end{array}$} & $\begin{array}{l}\varphi_{\mathrm{p} 1 \mathrm{j}}=\mathrm{a}_{1 \mathrm{j}}=\mathrm{g}_{1 \mathrm{j}}=0 \\
(\mathrm{p}=1,2 \ldots, 4 ; \mathrm{j} \neq 1 ; \text { d.f. }=30)\end{array}$ & $64.92 * * *$ \\
\hline & $\begin{array}{l}\varphi_{\mathrm{p} 21}=\mathrm{a}_{21}=\mathrm{g}_{21}=0 \\
(\mathrm{p}=1,2, \ldots, 4 ; \text { d.f. }=6)\end{array}$ & $21.37 * * *$ & & $\begin{array}{l}\varphi_{\mathrm{p} 1 \mathrm{j}}=\mathrm{a}_{12}=\mathrm{g}_{12}=0 \\
(\mathrm{p}=1,2 \ldots, 4 ; \text { d.f. }=6)\end{array}$ & $18.72 * * *$ \\
\hline & $\begin{array}{l}\varphi_{\mathrm{p} 31}=\mathrm{a}_{31}=\mathrm{g}_{31}=0 \\
(\mathrm{p}=1,2, \ldots, 4 ; \text { d.f. }=6)\end{array}$ & 8.90 & & $\begin{array}{l}\varphi_{\mathrm{p} 13}=\mathrm{a}_{13}=\mathrm{g}_{13}=0 \\
(\mathrm{p}=1,2 \ldots, 4 ; \text { d.f. }=6)\end{array}$ & $15.27 * *$ \\
\hline & $\begin{array}{l}\varphi_{\mathrm{p} 41}=\mathrm{a}_{41}=\mathrm{g}_{41}=0 \\
(\mathrm{p}=1,2, \ldots, 4 ; \text { d.f. }=6)\end{array}$ & $20.42 * * *$ & & $\begin{array}{l}\varphi_{\mathrm{p} 14}=\mathrm{a}_{14}=\mathrm{g}_{14}=0 \\
(\mathrm{p}=1,2 \ldots, 4 ; \text { d.f. }=6)\end{array}$ & 7.28 \\
\hline & $\begin{array}{l}\varphi_{\mathrm{p} 51}=\mathrm{a}_{51}=\mathrm{g}_{51}=0 \\
(\mathrm{p}=1,2, \ldots, 4 ; \text { d.f. }=6)\end{array}$ & 5.53 & & $\begin{array}{l}\varphi_{\mathrm{p} 15}=\mathrm{a}_{15}=\mathrm{g}_{15}=0 \\
(\mathrm{p}=1,2 \ldots, 4 ; \text { d.f. }=6)\end{array}$ & $18.41 * * *$ \\
\hline & $\begin{array}{l}\varphi_{\mathrm{p} 61}=\mathrm{a}_{61}=\mathrm{g}_{61}=0 \\
(\mathrm{p}=1,2, \ldots, 4 ; \text { d.f. }=6)\end{array}$ & 8.86 & & $\begin{array}{l}\varphi_{\mathrm{p} 16}=\mathrm{a}_{16}=\mathrm{g}_{16}=0 \\
(\mathrm{p}=1,2 \ldots, 4 ; \text { d.f. }=6)\end{array}$ & 4.55 \\
\hline $\begin{array}{l}\text { From DAX to } \\
\text { other(s) }\end{array}$ & $\begin{array}{l}\varphi_{\mathrm{pi} 2}=\mathrm{a}_{\mathrm{i} 2}=\mathrm{g}_{\mathrm{i} 2}=0 \\
(\mathrm{p}=1,2, \ldots, 4 ; \mathrm{i} \neq 2 ; \text { d.f. }=30)\end{array}$ & $131.87 * * *$ & $\begin{array}{l}\text { From other(s) } \\
\text { to DAX }\end{array}$ & $\begin{array}{l}\varphi_{\mathrm{p} 2 \mathrm{j}}=\mathrm{a}_{2 \mathrm{j}}=\mathrm{g}_{2 \mathrm{j}}=0 \\
(\mathrm{p}=1,2 \ldots, 4 ; \mathrm{j} \neq 2 ; \text { d.f. }=30)\end{array}$ & $73.51 * * *$ \\
\hline $\begin{array}{l}\text { From CAC40 to } \\
\text { other(s) }\end{array}$ & $\begin{array}{l}\varphi_{\text {pi3 }}=a_{i 3}=g_{i 3}=0 \\
(p=1,2, \ldots, 4 ; i \neq 3 ; \text { d.f. }=30)\end{array}$ & $5706.62 * * *$ & $\begin{array}{l}\text { From other(s) } \\
\text { to CAC40 }\end{array}$ & $\begin{array}{l}\varphi_{\mathrm{p} 3 \mathrm{j}}=\mathrm{a}_{3 \mathrm{j}}=\mathrm{g}_{3 \mathrm{j}}=0 \\
(\mathrm{p}=1,2 \ldots, 4 ; \mathrm{j} \neq 3 ; \text { d.f. }=30)\end{array}$ & $82.56 * * *$ \\
\hline $\begin{array}{l}\text { From ISEQ20 to } \\
\text { other(s) }\end{array}$ & $\begin{array}{l}\varphi_{\mathrm{pi} 4}=\mathrm{a}_{\mathrm{i} 4}=\mathrm{g}_{\mathrm{i} 4}=0 \\
(\mathrm{p}=1,2, \ldots, 4 ; \mathrm{i} \neq 4 ; \text { d.f. }=30)\end{array}$ & $84.55 * * *$ & $\begin{array}{l}\text { From other(s) } \\
\text { to ISEQ20 }\end{array}$ & $\begin{array}{l}\varphi_{\mathrm{p} 4 \mathrm{j}}=\mathrm{a}_{4 \mathrm{j}}=\mathrm{g}_{4 \mathrm{j}}=0 \\
(\mathrm{p}=1,2 \ldots, 4 ; \mathrm{j} \neq 4 ; \text { d.f. }=30)\end{array}$ & $76.94 * * *$ \\
\hline $\begin{array}{l}\text { From FTSEMIB } \\
\text { to other }(\mathrm{s})\end{array}$ & $\begin{array}{l}\varphi_{\mathrm{pi} 5}=\mathrm{a}_{\mathrm{i} 5}=\mathrm{g}_{\mathrm{i} 5}=0 \\
(\mathrm{p}=1,2, \ldots, 4 ; \mathrm{i} \neq 5 ; \text { d.f. }=30)\end{array}$ & $105.66 * * *$ & $\begin{array}{l}\text { From other(s) } \\
\text { to FTSEMIB }\end{array}$ & $\begin{array}{l}\varphi_{\mathrm{p} 5 \mathrm{j}}=\mathrm{a}_{5 \mathrm{j}}=\mathrm{g}_{5 \mathrm{j}}=0 \\
(\mathrm{p}=1,2 \ldots, 4 ; \mathrm{j} \neq 5 ; \text { d.f. }=30)\end{array}$ & $44.68 * * *$ \\
\hline $\begin{array}{l}\text { From WIG20 to } \\
\text { others }\end{array}$ & $\begin{array}{l}\varphi_{\mathrm{pi} 6}=\mathrm{a}_{\mathrm{i} 6}=\mathrm{g}_{\mathrm{i}}=0 \\
(\mathrm{p}=1,2, \ldots, 4 ; \mathrm{i} \neq 6 ; \text { d.f. }=30)\end{array}$ & $50.87 * *$ & $\begin{array}{l}\text { From others to } \\
\text { WIG20 }\end{array}$ & $\begin{array}{l}\varphi_{p 6 j}=a_{6 j}=g_{6 j}=0 \\
(p=1,2 \ldots, 4 ; j \neq 6 ; \text { d.f. }=30)\end{array}$ & $95.45 * * *$ \\
\hline
\end{tabular}

Note: FTSE100, DAX, CAC40, ISEQ20, FTSEMIB and WIG20 are, respectively, indexed as 1, 2, 3, 4, 5 and 6. Paired interactions between DAX, CAC40, ISEQ20, FTSEMIB and WIG20 can be found in Tables 1 and 2 of the supplement material. 